\title{
Sağlık Çalışanlarının Psikolojik Yıldırma ve Algılanan Sosyal Destek Düzeylerinin Íncelenmesi: Konya İlinde Bir Uygulama ${ }^{1}$
}

\author{
Investigation of Psychological Mobbing and Perceived Social Support Levels of \\ Health Workers an Application in Konya Province
}

\author{
Sevda KARA * \\ Ş. Didem KAYA **
}

$\ddot{O} Z$

Psikolojik yıldırma, baskı ya da zorbalık şeklinde tanımlanmaktadır. Sosyal destek ise ihtiyacı olan kişiye yardım eli uzatabilen kişilerin sayısını kapsamaktadır. Psikolojik yıldırma ile baş etme yollarından biri de sosyal destektir. Bu çalışmanın amacı; sağlık çalışanlarının psikolojik yıldırma ile algılanan sosyal destek düzeylerinin incelenmesi ve iki kavram arasındaki ilişkinin tespit edilmesidir. Çalışma, tanımlayıcı tipte bir araştırmadır. Çalışma Eylül 2016-Ocak 2017 tarihleri arasında Konya ilinde bir üniversite hastanesi ve bir devlet hastanesinde yapılmıştır. Araştırmanın evrenini toplam 2901 sağlık çalışanından, örneklem büyüklüğ̈̈ ise 345 kişiden oluşmaktadır. Çalışmada Aiello ve diğ. (2008) tarafindan geliştirilen ve Türkçe uyarlaması Laleoğlu ve Özmete (2013) tarafindan yapılan Mobbing Ölçeği ile Zimet ve diğ. (1988) tarafindan geliştirilen ve Türkçe uyarlaması Eker ve diğ. (2001) tarafindan yapılan Çok Boyutlu Algılanan Sosyal Destek Ölçeği kullanılmıştır. Verilerin analizinde; yüzde, ortalama, standart sapma, t testi, ANOVA testi, korelasyon ve regresyon analizinden yararlanılmıştır. Araştırmaya katılanların \%54,2'si kadın, \%45,8'i ise erkektir.

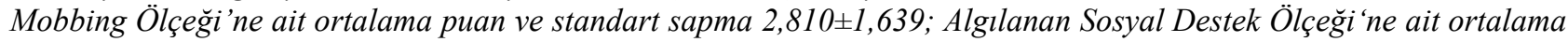
puan ve standart sapma 5,684 0,245 olarak bulunmuştur. Cinsiyet, yaş, eğitim durumu, unvan değişkenlerine göre Psikolojik Yıldırma puanları arasında anlamlı düzeyde farklılık bulunmuştur $(p<0,05)$. Cinsiyet, yaş, unvan ve mesleki deneyim değişkenine göre Algılanan Sosyal Destek puanı arasında anlamlı düzeyde farklılık çıkmıştır $(p<0,05)$. Yapılan korelasyon analizi sonucunda çalışanların psikolojik yıldırma düzeyleri ile algılanan sosyal destek düzeyleri arasında negatif yönlü ve düşük düzeyde ilişki bulunmuştur $(r=-0,154 ; p<0,01)$. Algllanan sosyal destek düzeyinin, psikolojik yıldırma algısı üzerindeki etkisi \%2,4 oranında açıklanmaktadır. "Sağlık çalışanlarının algılanan sosyal destek düzeyi arttıkça psikolojik yıldırma düzeyi azalmaktadır” şeklinde söylenebilmektedir.

\author{
ANAHTAR KELIMELER \\ Algılanan Sosyal Destek; Mobbing; Psikolojik Yıldırma; Sağlık Çalışanları
}

\begin{abstract}
Psychological intimidation is defined as oppression or bullying. Social support covers the number of people who can help the person in need. One way of coping with psychological intimidation is social support. The aim of this study is; The aim of this study is to investigate the perceived social support levels of health workers with psychological intimidation and to determine the relationship between two concepts. The study is a descriptive study. The population of the study consists of a total of 2901 health workers and a sample size of 345 people. Aiello et al. (2008) and the Turkish adaptation of the Mobbing Scale by Laleoğlu and Özmete (2013) and Turkish adaptation developed by Zimet et al. (1988), Eker et al. (2001) by the Multidimensional Scale of Perceived Social Support was used. In the analysis of data; Percentage, mean, standard deviation, $t$ test, ANOVA test, correlation and regression analysis were used. \%54,2 of the participants were female and \%45,8 were male. The mean score and standard deviation of the Mobbing Scale were 2,810 $\pm 1,639 ;$ The mean score and standard deviation for the Perceived Social Support Scale were found to be 5,684 \pm 0,245. According to gender, age, educational status, title variable, there was a significant difference between Psychological Intimidation scores ( $p$ <0.05). There was a significant difference between Perceived Social Support score according to gender, age, title and professional experience variable ( $p<0.05)$. As a result of the correlation analysis, a negative correlation was found between the levels of psychological intimidation and perceived social support of the employees $(r=-0,154 ; p$ $<0,01)$. The impact of perceived social support on the perception of psychological intimidation is \%2,4. As the perceived social support level of health workers increases, the level of psychological intimidation decreases ".
\end{abstract}

\section{KEYWORDS}

Perceived Social Support; Mobbing; Psychological Intimidation; Health Workers

\begin{tabular}{|c|l|c|}
\hline \multicolumn{2}{|c|}{ Makale Geliş Tarihi / Submission Date } & \multicolumn{1}{c|}{ Makale Kabul Tarihi / Date of Acceptance } \\
15.06.2021
\end{tabular}

\footnotetext{
${ }^{1}$ Bu çalışma Doç. Dr. Ş. Didem Kaya'nın danışmalığında yürütülen “Sağlık Çalışanlarının Psikolojik Yıldırma ve Algılanan Sosyal Destek Düzeylerinin İncelenmesi: Konya İlinde Bir Uygulama” başlıklı yüksek lisans tezinden üretilmiştir.

*Hemşire, Necmettin Erbakan Üniversitesi Meram Tıp Fakültesi Hastanesi, nikirik1987@ hotmail.com, ORCID: 0000-0001-2345-6789

** Doç. Dr., Necmettin Erbakan Üniversitesi Sağl1k Bilimleri Fakültesi, dkaya@erbakan.edu.tr, ORCID: 0000-0003-0729-1886
} 


\section{GİRIŞ}

Mobbing kavramı; psikolojik yıldırma, psikolojik şiddet, iş yeri zorbalığı ve psikolojik taciz gibi kavramlar ile de adlandırılmaktadır. Bu çalışmada mobbing kavramı psikolojik yıldırma olarak kullanılmaktadır. Leymann, psikolojik yıldırmayı bir ya da birkaç kişi tarafından diğer kişiye yönelik sistematik bir biçimde, düşmanca ve ahlak dışı davranışlarda bulunulması ve bu davranışlar sonucunda da kişinin savunmasız ve çaresiz bir duruma itilmesi olarak tanımlamaktadır. Psikolojik yıldırma, iş yerinde çatışmalara ve farklı sorunlara yol açabilmektedir. İş yerinde psikolojik yıldırmanın amacı mağdurun üzerinde psikolojik baskı uygulayarak; 1srarlı yıldırıcı, aşağılayıcı haksız söz ve ithamlarla onur kırıcı davranışlarda bulunarak mağdurun işten ayrılmasını sağlamaktır (Yıldırım, 2009: 12-15). Psikolojik yıldırma, güçlü olan çalışanların, güçsüz olan çalışanlara uyguladığı sürekli, odaklanmış ve zarar veren bir iletişim şekli olarak da ortaya çıkmaktadır (Sandvik, 2003: 5-6).

Sosyal destek ve algılanan sosyal destek ise kişileri hayata bağlamak ve bireyin çevresindeki insanlarla etkileşimleri sırasında algıladığı olumlu destektir ve her anlamda önemli hissettirmektir. Sosyal destek genel olarak kişi zorluklarla karşılaştığında çevresindekilerin verdiği destek ve yardımı kapsamaktadır. Ayrıca bu yardımlardan kasıt sadece psikolojik yardımlar olmayıp fiziksel yardımlar da olabilmektedir (Özyolcu, 2015: 55). Algilanan sosyal destek ise stres altındaki bireylerin ayakta durabilmelerine yardım edebilecek ya da olmadığı durumlarda kişinin hayatında fazladan risk faktörü olma özelliği taşıyan önemli bir kaynak olarak var olmaktadır (Mete, 2017: 26). Eğer bireyin algılanan sosyal destek düzeyi yüksek olursa psikolojik yıldırma düzeyinin bireye verdiği zarar da düşme gözlenebilir. Bu ters ilişkinin araştırılması sağlık çalışanlarına algılanan sosyal desteğin psikolojik anlamda nasıl faydalı olabileceğinin ve yıldırmanın nasıl azaltılabileceği hakkında yardımcı olabileceği düşünülmektedir.

\section{KURAMSAL ÇERÇEVE}

\subsection{Psikolojik Yıldırma Olgusu}

İngilizce bir kelime olan "mobbing" kelimesi "şiddetle alakalı ve yasaya uygun olmayan kalabalık" anlamına gelen "mob" kelimesinden türemiştir. "Mob" kelimesinin etimolojik kökeni Latince'den gelen "kararsız kalabalık" olarak Türkçeye çevirebileceğimiz "mobile vulgus" kelimesine dayanmaktadır (İlhan, 2010: 2). Mobbing kavramı; psikolojik yıldırma, psikolojik şiddet ve psikolojik taciz gibi kavramlar ile de adlandırılmaktadır. Bu terim ilk olarak Konrad Lorenz tarafından literatüre kazandırılmıştır. Daha sonra ise; çocuklar arasında anlaşmazlıkları inceleyen Heinemann tarafından kullanılmıştır. Hayvan davranışlarını inceleyen Lorenz psikolojik yıldırma kavramını 1960'larda bir grup küçük hayvanın daha büyük tek bir hayvanı (bir grup kazın bir tilkiyi) korkutmak için yaptıkları saldırılarını tanımlamak amacıyla kullanmıştır. Heinemann ise ders ortamında ögrencileri gözlemlemiş ve birbirlerine neler yapabileceğiyle ilgilenmiş ve küçük gruplardaki çocukların genelde tek bir çocuğu hedef alarak ona yönelik yıkıcı, saldırgan ve zararlı davranışlarını tanımlamak amacıyla kullanmıştır (Tetik, 2010: 1-2).

\subsubsection{Psikolojik Yıldırma Kavramı}

Psikolojik yıldırma bireyi çalışma hayatında engelleyici kötü davranışlara maruz bırakarak, taciz eden, bilinçli olarak uygulanan ve tedavisi mümkün olmayan birtakım rahatsızlıklara neden olan, zamanla kişiye ciddi ölçüde acı veren ve rahatsızlık hissettiren tutum ve davranışların devamlılık arz etmesiyle gelişen süreç içerisinde meydana gelen bir kavramdır (Karabacak ve Hacıcaferoğlu, 2020: 2443). Diğer bir tanımla psikolojik yıldırma; bireyin karakterini, onurunu, gururunu ayrıca fiziksel ve ruhsal bütünlügünü aşağılayarak mesleğini yapmasına engel oluşturacak bütün fiili, sözlü, yazılı davranışları içeren kötü niyetli yaklaşımlardır (Hirigoyen, 2000: 61).

Uluslararası Çalışma Örgütü (ILO), psikolojik yıldırma kavramını "intikamcı, acımasız, şeytanca ve onur kırıcı eylemler aracılığ 1 ile bir veya bir grup çalışana zarar vermeyi amaçlayan saldırgan davranış" şeklinde tanımlanmıştır (Chappell ve Di Martino, 1998: 2). While Field (1996), psikolojik yıldırma için 'bullying' kavramını kullanmıştır. Bu kavramla anlatılmak istenen, kişinin işyerinde tekrarlanan eleştiriler, aşağılayıcı söz ve davranışlar, yüksek sesle azarlamalar gibi düşmanca bir dizi davranışa maruz kalmasıdır. Field'e göre psikolojik yıldırma, maruz kalan kişinin öz benliğini zedeleme veya öldürme çabası için yapılmaktadır. Bu davranışın altında bulunan ana sebep ise; yok etme, üstünlük kurma ve buyruğu altına alma arzusudur. Vickers ise psikolojik yıldırma ile ilgili açıklamasında, başkalarına acı verme ve verilen acıdan zevk duyma durumuna işaret etmektedir (Yöney ve Kılınç, 2020: 4). Psikolojik yıldırmaya maruz kalan kişiler gördükleri zarara bağlı olarak "işiyle yeterince ilgilenemez, adapte olamaz ve ilerleyen süreçte görevini yerine getiremez" konuma gelmektedirler. 


\subsubsection{Sağlık Kurumlarında Psikolojik Yıldırma}

Çalışma temposunun yoğun olması, stresin en üst düzeyde yaşanması, farklı meslek gruplarının bir arada bulunması ve hizmet verilecek kişilerle birebir temas halinde olması sebebiyle sağlık çalışanları diğer sektörlerde çalışanlara oranla daha fazla yıldırmaya maruz kalmaktadır (Çimen ve Deniz, 2017: 221). İş yerinde veya bulunduğu sosyal ortamda yıldırma davranışlarına maruz bırakılan kişi, fiziksel ve ruhsal sağlığın bozulması, iş yaşantısı ve sosyal hayatta depresyon gibi birçok farklı yönden zarar görebilmektedir (Karabacak ve Hacıcaferoğlu, 2020: 2443). Bu sebeple, sağlık çalışanlarının, sağlık kurumlarının ve hastaların güveni için psikolojik yıldırma alanında pek çok çalışma yapılmıştır. Hubert ve Veldhoven (2001: 417) yaptıkları çalışmada, eğitim hizmetlerinde, kamu yönetiminde ve sağlık hizmetlerinde diğerlerine göre yıldırmanın daha fazla olduğunu saptamışlardır. Sağlık ekibi üyeleri arasında hemşirelerin psikolojik yıldırmaya daha fazla maruz kaldıkları belirtilmektedir. Yıldırım ve Yıldırım (2007: 1449) kamu hastanesi ile özel hastanede çalışan 505 hemşirenin \%86,5'sının son bir yılda iş yerinde psikolojik yıldırma davranışı ile karşılaştığını, Karcıoğlu ve Akbaş (2010: 139), kamu hastanesinde çalışan 210 hemşirenin \%38,6'sının psikolojik yıldırma mağduru olduğunu belirlemiştir. Türkiye'de yapılan bir araştırmada sağlık çalışanlarının \%5,2'sinin, Avustralya'da bir kamu hastanesinde yapılan çalışmada çalışanların \%26'sının, Norveç’te 7986 çalışana ulaşılan bir çalışmada çalışanların \%8,6'sının psikolojik yıldırmaya maruz kaldıkları belirlenmiştir (Çimen ve Deniz, 2017: 230). TBMM 2011: 25-26) yayınlamış olduğu 'İş yerinde Psikolojik Taciz (Mobbing) ve Çözüm Önerileri Raporunda", iş yerinde psikolojik şiddetin sıklıkla yaşandığı sektörlerin başında sağlık sektörü olduğu ve sağlık çalışanlarının şiddete uğrama riskinin diğer meslek gruplarına göre 16 kat daha fazla olduğu belirlenmiştir. Raporda, İstanbul'da 505 hemşireyi kapsayan bir çalışmada da hemşirelerin \%86'sının psikolojik tacize maruz kaldığı belirtilmiştir. Weber ve diğ. (2007: 267), Almanya'da hemşirelerin psikolojik yıldırmaya maruz kalma oranlarının \%3, Avrupa'da ise \%2 ile \%15 arasında değiştiğini belirtmektedir. Güney Afrika'da kamu ve özel hastanelerde çalışan 1044 sağlık çalışanın \%60-70'inin, Portekiz'de sağlık sektöründe çalışanların \%51'inin, Jamaika'da 832 sağlık çalışanın \%46'sının psikolojik yıldırma yaşadığı saptanmıştır (Kılıç ve Tel, 2017: 35). Pai ve Lee (2011: 1412) Tayvan'da çalışan hemşirelerin işyerinde karşılaştı̆̆ psikolojik yıldırma davranışlarını ve bu davranışların etkilerini belirlemek amacıyla 521 hemşire üzerinde yaptıkları çalışma sonucunda; katılımcılardan, $155(\% 29,8)$ 'i psikolojik yıldırmaya, $67(\% 12,9)$ 'si cinsel tacize, $268(\% 51,4)$ 'i sözlü tacize maruz kaldıklarını ve $102(\% 19,6)$ ' sinin de fiziksel şiddet yaşadığını saptamışlardır. Heather ve diğ., (2010: 2732)'nin Kanada'daki hastane ortamlarında yıldırma davranışının tükenmişlik düzeyine etkisini belirlemek amacıyla 415 hemşire üzerinde yaptıkları çalışma sonucunda; yıldırmaya maruz kalmak ve tükenmişlik düzeyi arasında anlamlı bir ilişki olduğunu saptanmışlardır.

İngiltere'de psikolojik yıldırma ile ilgili yapılan çalışmalarda en çok önem verilen konu eğitim olarak ifade edilmektedir. Bu konuda çalışanlara; farkındalığın arttırılması, şiddet ile ilgili detaylı bilgi verilmesi ve korunma yöntemleri gibi üç aşamalı özel eğitimler verilmesi, bilinçli bir örgüt yapısını oluşturarak psikolojik yıldırma ile ilgili ciddi bir farkındalık artışını sağlamıştır. İngiltere'de, Sağlık Bakanlığının önderliğinde 14.10.1999 tarihinde, "Ulusal Sağlık Hizmetlerinde Çalışan Personele Yönelik Şiddeti Durdurma Kampanyası: Ulusal Sağlık Hizmetlerinde Şiddete Sıfır Tolerans" kampanyası başlatılmıştır (Department of Health, 1999: 226). İsveç, psikolojik yıldırmaya karşı özel yasal düzenleme yapan ilk AB ülkesidir. Türkiye mobbing kavramı ile ilk defa; işverene işyerinde psikolojik tacizi engelleme yükümlülüğü getiren Borçlar Kanunu Tasarısı ile tanışmıştır. Genelde kadınlar üzerinden yürüdüğü sanılan mobbing, erkekleri de aynı şiddete mağdur etmektedir. Mağdurları genelde kadın olmasına rağmen, ülkemizdeki ilk mobbing davasını bir erkek bürokrat açmıştır (TBMM, 2011: 11). Kowalczuk ve diğ. (2007: 90)'da Polonya'da çalışan 501 doktorun yıldırma konusundaki tepkilerini araştırmışlardır. Doktorların \%33'nde üstlerinin uyguladığı ses yükseltmesi, \%16'sının diğer meslektaşlarının yanında üstlerinin uygunsuz davranışlarda bulunduğu, \%11'inin de hasta yanlarında yıldırma davranışları yaşadıkları belirtilmiştir.

\subsubsection{Psikolojik Yıldırma ile Mücadele Yöntemleri}

\subsubsection{Psikolojik Yıldırma ile Bireysel Mücadele Yöntemleri}

Psikolojik yıldırma sürecinde ayakta kalabilmek için üst düzey bilinçlenmenin sağlanması ve bu yöntemle kişinin kendisine karşı olan güvenini ayakta tutmaya çalışması gerekmektedir. Bireyin ilk önce kendisine karşı duyduğu özgüveni arttırmak çok önemlidir. Özgüven, bireyin tek başına bu sürece sağlıklı bir şekilde katılımını sağlayan bir yetenektir (Göymen, 2020: 18). Yine bu noktada kişinin yapması gereken en önemli karşı koyma yöntemi hedef olmayı kabullenmemektir. Çünkü genelde baskıyı hisseden çalışanların ilk yaptığı davranış korkmak, sinmek ve dolayısıyla hedef olmayı kabul etmektir (Sönmeztekin, 2016: 76). Bireysel anlamda en önemli başa çıkma yöntemleri; güven, özgüven ve bilinçlenme, duyguları kontrol etme, soğukkanlı 
olmaya çalı̧̧mak, meditasyon yapmak, dinlenmek, hobi edinmek, dengeli ve düzenli beslenmek, düzenli olarak spor yapmak, kendisini eğitmeye ve geliştirmeye çalışmak olarak sıralanabilmektedir (Kırel, 2008: 84).

\subsubsection{Aile ve Yakın Çevrenin Yapabileceği Sosyal Destek}

Psikolojik yıldırma sürecinde kurban en büyük desteği ailesi tarafından görmek istemektedir. Kurbanın en çok güveneceği kişiler ailesini kapsamaktadır. İş hayatında yaşadığı olguyu her seferinde ailesiyle paylaşabilmektedir. Ailesinin hak verdiğini bilmek kurbanı rahatlatabilmektedir. Ailenin seçimi kurbanı dinlemeye yönelik olmalıdır (Çetinkaya, 2016: 37).

\subsubsection{3. Örgütsel Mücadele Yöntemleri}

Örgütte açık yönetim anlayışının benimsenmesi psikolojik yıldırmayı engellemenin etkili yöntemlerinden biridir. Yönetim, örgüt içindeki problemlerin ve bu problemlerin çözümü için gereken düşüncelerin ast üst ilişkisi çerçevesinde düzenlenmesini sağlamalıdır. Böyle bir durum söz konusu olduğunda psikolojik yıldırma yaşayan kişiler bu durumu yönetime çekinmeden aktarabilirler. Aynı zamanda saldırmaya yatkın olan kişilerin kurumun politikasının farkında olması da bireyi yıldırma konusunda engellemektedir (Hogh ve Dofradottir, 2001: 485).

Psikolojik yıldırmanın çalışma ortamında meydana gelmemesi amacıyla liderlik anlayışııın farklılaşması da gerekmektedir. Bu anlayışa göre lider bireylere rol model olmalıdır. Liderin rol model olması bireyler tarafından örnek teşkil ederek bu durum çalışanlar açısından örgüt kültürü olarak düşünülür ve bütün bireyler aynı modele uyum sağlamaktadır (Resch ve Schubinski, 1996: 295). Örgütsel sağlığın olması da psikolojik yıldırmayı etkilemektedir. Miles (1969: 378)'e göre örgütün sağlıklı olması demek, sadece etrafında yaşamını devam ettirmek değil, aynı zamanda devamlı gelişmekte olan, sorunlarla baş etmede ve yaşama yeteneklerini geliştiren örgütü ifade etmektedir.

Türkiye'de mobbingle mücadele amaciyla Alo 170 mobbing mücadele hattı kurulmuştur. $\mathrm{Bu}$ hatt1 arayanlardan \%57'sinin erkek, \%43'ünün ise kadın olduğu belirtilmektedir. Bu hattı arayanların genel şikayet sebepleri ise ilk olarak istifaya zorlama, daha sonra görev yeri değişikliği, hakaret ve kötü söz söyleme, yasal hak kullanımını ihlal etmek, iftira atmak, fiziksel şiddet ve son olarak da cinsel taciz şeklinde sıralanmaktadır (Zencirkıran ve Keser, 2018: 245).

\subsection{Sosyal Destek}

Sosyal destek, ihtiyacı olan kişiye yardım eli uzatabilen kişilerin sayısını kapsamaktadır. Sosyal destek, kişinin sosyal ilişkilerinin niceliğinden çok niteliğini kapsayan bir olgudur. Yani kişinin ilişkili olduğu birey sayısından çok manevi olarak paylaşımda bulunabileceği, güven duyduğu ve kendisinin özel olarak nitelediği kişiyle kurduğu bağdaki sosyal desteği içermektedir (Ardahan, 2006: 2). 1970'li y1llarda literatürdeki yerini alan sosyal destekten; Cassel (1976: 108), sosyal çevrenin ve sosyal desteğin bireyin stresle ve olumsuz durumlarla başa çıkmadaki etkisinden bahsetmektedir ve insan sağlı̆̆ının devamı için psiko- sosyal süreçlerin önemini vurgulamaktadır.

Yalnızlık, yaşlılıktan ziyade daha çok genç ve ergenlerde görülen değişik duyguları kapsayan; kaygı, öfke, üzüntü ve kendini farklı görme gibi istenmeyen ve hoş olmayan bir durum olarak ortaya çıkmaktadır (Çeçen, 2008: 2). Yeni doğan bir bebeğin bile çevresinin yardımı olmadan yaşamını sürdürmesi mümkün değildir. Yaşamına devam edebilmesi için doğumdan itibaren çevresindeki insanlarla iletişim içine girmektedir. Bireyler, sosyal dünyasındaki çabalarını sadece toplum içindeki diğer bireylerle kurduğu sosyal ilişkiler sayesinde sağlamaktadır (Kozakl1, 2006: 43). Redmann (2006: 168) yapılan araştırmaların, farklı türdeki sosyal desteğin kişiler üzerinde aynı ölçüde etkili olmayacağını göstermiştir. Bu nedenle bireyin ne ölçüde hangi yoğunlukta desteğe ihtiyacı olduğunu belirlemek önemlidir. Eğer birey ihtiyacı olan türde ihtiyac1 olduğu kadar destek alırsa, o bireyde olumlu etkiler ve davranışlar oldukça yüksek olmaktadır.

\subsubsection{Sosyal Desteğin Boyutları}

Sosyal destek kişisel ve örgütsel olmak üzere iki gruba ayrılmaktadır. Kişisel sosyal destek, kaynakları bireyin gerek iş ortamında ya da hayatına ilişkin olaylarla ilgili başa çıkma potansiyelini attırmaktadır. Kişisel sosyal destek kaynakları başta aile üyeleri, eşler ve arkadaşları kapsar. Örgüt kökenli sosyal destek kaynakları ise örgüt, yöneticiler ve çalışma arkadaşlarını kapsar. Örgütten, yöneticiden ve çalışma arkadaşlarından gelen destek bireyin işe ilişkin becerilerini sürdürmede ve işe bağlllığında oldukça etkilidir (Kurt, 2013: 28-29). Bruhn ve Philips (1984: 151-152), sosyal desteğin nitel ve nicel boyutlardan oluştuğunu, zamana ve duruma göre değişebilen bir kavram olduğunu ve bireylerin ihtiyaçları doğrultusunda değiştiğini belirtmektedir. 


\subsubsection{Algilanan Sosyal Destek}

Algılanan sosyal destek, stres altındaki bireylerin ayakta durabilmelerine yardım edebilecek ya da olmadığı durumlarda kişinin hayatında fazladan risk faktörü olma özelliği taşıyan önemli bir kaynak olarak var olmaktadır (Mete, 2017: 26). Başka bir ifadeyle bireylerin başkaları ile güven veren bağlara sahip olduğu ve bu bireylerden kendisine destek sağlanacağına dair düşüncesi olarak tanımlanabilmektedir. Sorensen ve Pinquart (2010: 248)'a göre algılanan sosyal destek, iyimserlik, dışa dönüklük, yalnızlık düzeyi, nevrotizm ve düşmanca duygular üzerinde etkili olmaktadır. Bireyin stresle başa çıkma yolları ve algıladıkları sosyal destek üzerine yapılan araştırma sonucu aileden, arkadaştan ve özel bir bireyden algılanan sosyal destek arttıkça, stresle etkili başa çıkma yolları yöntemlerinin arttığı tespit edilmiştir (Özdemir, 2017: 61). Kişilerin hayatında çoğu dönemde oldukça önemli etkisi olan destek aileden sağlanan sosyal destektir. Sosyal destek kuramı, ailenin verdiği desteğin bireyin hayatında yaşadığı strese yönelik azaltıcı etkisi bulunduğuna, fiziki sağlık ve mental sağlık anlamında da koruma amaçlı etkisi olduğu bilinmektedir. Diğer bir sosyal destek kaynağı ise arkadaşlardan alınan destektir. Arkadaştan alınan destek ergenlikten itibaren, yaşamın bütün dönemlerinde kişi açısından en kıymetli olan aile desteğinin verdiği etkiyle eşit olmakla birlikte, bazen aileden üstün olabilen sosyal destek türüdür (Yıldırım, 2017: 33).

Alan yazında sosyal destek kavramı ile ilgili açılamalar yapılırken algılanan ve sağlanan sosyal destek ifadeleri görülmektedir. Algılanan ve sağlanan sosyal destek kavramları farklı iki kavramdır. Algılanan sosyal destek bireyin ihtiyaç duyduğunda yardım davranışının ortaya çıkacağına dair inanç ve kişisel bir değerlendirme iken sağlanan sosyal destek diğer insanlar tarafından gösterilen, gerçeklemiş yardım davranışıdır (Akeren, 2017: 32).

\subsubsection{Sağlık Kurumlarında Algılanan Sosyal Destek}

Sosyal destek konusunda yapılan çalışmalarda iki önemli nokta üzerinde durulmuştur. Bunlardan ilki, sosyal desteğin sağlık ile doğrudan ilişkili olduğunu belirtmektedir. İkinci yaklaşımda ise sosyal desteğin en önemli görevi stres verici olayların bireye verdiği zararları azaltarak ya da dengeleyerek ruh sağlını korumasıdır. (Elmacı, 2006: 408). Ayrıca araştırmalar farklı kaynaklardan elde edilen farklı türlerdeki sosyal desteğin bireyler üzerinde aynı düzeyde etkili olmadığını göstermektedir. Sosyal desteğin etkisini belirleyen en önemli konu bireyin ne tür desteğe ihtiyacının olduğudur. Eğer birey sosyal desteğe ihtiyacı olduğu zamanda ve ihtiyaç duyduğu türde destek alabilirse, bu desteğin pozitif etkisi de oldukça yoğun olacaktır (Redman, 2006: 168).

Abualrub (2004: 73) hemşireler üzerinde yaptığı sosyal destek araştırmasında; iş arkadaşlarından algılanan sosyal desteğin, iş performansını arttırdığını ve iş stresi seviyesini azalttığını saptamıştır. Sosyal desteğin fiziksel ve psikolojik sağlık açısından önemli bir kaynak olduğu ve tedavi edici bir özelliğinin olduğu kabul görmektedir. Pearson (1986: 391), yaptığı araştırma sonucunda sosyal destek görme ile ölüm oran arasında anlamlı ve ters yönlü bir ilişki bulmuştur.

Kaya ve diğ. (2012: 362)'nin sağlık kurumunda birim sorumluları üzerinde yaptığı çalışma sonucunda sosyal desteğin, iş yerindeki stresin olumsuz etkilerine yönelik, doğrudan mutluluk kaynağı olarak tampon görevi gören ve stres seviyesinin azaltılmasında etkili rol oynayan, depresyonu azaltmaya yarayan ve bağışıklık sistemini de olumlu yönde etkilediğini ve sosyal desteğin bir kür etkisi gösterdiğini ifade etmişlerdir.

Akın (2008: 160), hemşireler üzerinde sosyal desteğin, örgütsel destek, iş-aile çatışmaları ve yaşam doyumu ile ilişkilerini incelediği araştırmada; sosyal destekle yaşam doyumu arasında pozitif yönde ilişki olduğu, algılanan örgütsel desteğin iş, aile çatışması ile anlamlı ve negatif yönde ilişkisi olduğu bulgularını elde etmiştir. Ayrıca araştırmacı, kişinin iş örgütünden elde ettiği destek arttıkça, bu durumun iş-aile çatışmasını azalttığ 1 ve sosyal desteğin yaşam doyumu ile pozitif yönde anlamlı ilişkisi olduğunu bulmuştur.

Sosyal destek özellikle sağlık kurumlarında psikolojik yıldırmaya yönelik büyük önem taşımaktadır. Çalışanlar ailelerinden, meslektaşlarından ve gerektiğinde üstlerinden yeterince sosyal destek alırlarsa psikolojik yıldırmaya yönelik dirençleri artmaktadır.

\section{MATERYAL VE METOT}

\subsection{Araştırmanın Amacı}

Çalışmanın amacı, Konya ilinde bir üniversite hastanesi ve bir devlet hastanesinde hizmet veren sağlık çalışanlarının psikolojik yıldırma ile algılanan sosyal destek düzeylerinin incelenmesi ve iki kavram arasındaki ilişkinin tespit edilmesidir. 


\subsection{Araştırmanın Evreni ve Örneklemi}

Araştırmanın evrenini 2017 yılı Konya ilinde bulunan bir üniversite hastanesinde ve bir devlet hastanesinde çalışan sağlık çalışanları [hekim, hemşire, hasta bakıcı, tıbbi sekreter ve diğer sağlık personeli (teknisyen, laborant, temizlik personeli)] oluşturmaktadır. Çalışma evreni olarak hastane bilgi işlem biriminden alınan bilgiye göre; hekim (763), hemşire (871), hasta bakıcı (376), tıbbi sekreter (538) ve diğer sağlık personeli (353) olmak üzere toplam 2901 sağlık çalışanından oluşmaktadır. Herhangi bir özel hastaneden izin alınamadığ için araştırma bir devlet ve bir üniversite hastanesiyle sınırlandırılmıştır

\subsection{Araştırmanın Etik Boyutu}

Araştırmanın etik izni İlaç ve Tıbbi Cihaz Dışı Araştırmalar Etik Kurulu'nun 2016/567 sayılı kararı ile alınmıştır. Hastane çalışanlarına anket uygulamak amacıyla hastane başhekimliklerinden yazılı izin alınmıştır. Ayrıca, anket formunun uygulanması sırasında araştırmayı kabul eden çalışanlardan da bilgilendirilmiş yazılı onam alınmıştır.

\subsection{Verilerin Toplanması ve Veri Toplama Araçları}

Konya ilinde bir devlet ve bir üniversite hastanesi olmak üzere bu hastanelerde çalışan sağlık personellerine ulaşabilmek için Eylül 2016-Ocak 2017 ayları arasında, çalışmayı kabul eden hastanelerde çalışan hemşire, hekim, hasta bakıcı, tıbbi sekreter ve diğer sağlık personeli (teknisyen, laborant, temizlik personeli) şeklindeki gruplarla veri toplama işlemi gerçekleştirilmiştir. Veri toplama formu; tanımlayıcı özellikler (cinsiyet, yaş, medeni durum, eğitim durumu, statü, mesleki deneyim, çalışılan kurumdaki mesleki deneyim ve çalışılan birim), psikolojik yıldırma ve algılanan sosyal destek düzeyi ölçeğini içeren üç bölümden oluşmaktadır.

Mobbing Ölçeği (çalışmada mobbing ifadesi için psikolojik yıldırma kavramı kullanıldığından ölçek için de psikolojik yıldırma ölçeği ifadesi kullanılmıştır), Aiello ve diğ. (2008:9-24) tarafından geliştirilmiş ve Türkçeye uyarlaması çalışması Laleoğlu ve Özmete (2013: 19-20) tarafından yapılmıştır. 7'li Likert tipinde olup 38 madde ve 5 alt boyuttan oluşmaktadır. Alt boyutlar; iş arkadaşları ile ilişkiler, tehdit ve taciz, iş ve kariyer ile ilgili engellemeler, özel yaşama müdahale ve işe bağl1lık şeklinde sıralanmaktadır. Mobbing Ölçeği'nin Cronbach Alpha katsayısı 0,778 olarak ölçülmüştür. Mobbing ölçeğinin iş arkadaşları ile ilişkiler boyotunun $\alpha$ katsayısı 0,550 , tehdit ve taciz boyutunun $\alpha$ katsayısı 0,543 , iş ve kariyer ile ilgili engellemeler boyutunun $\alpha$ katsayıs1 0,541 , özel yaşama müdahale boyotunun $\alpha$ katsayısı 0,552 ve işe bağl1lık boyotunun $\alpha$ katsayısı ise 0,499 olarak ölçülmüştür. Çok Boyutlu Algılanan Sosyal Destek Ölçeği ise Zimet ve diğ. (1988: 30-41) tarafından geliştirilmiş ve Türkçeye uyarlaması Eker ve diğ. (2001: 17-25) tarafindan yapılmıştır. Toplam 12 maddeyi kapsamaktadır. Ölçeğe verilebilecek yanıtlar 1 ile 7 arasında değişmektedir. Ölçek 3 alt boyuttan oluşmaktadır. Alt boyutlar; özel bir insan, aile ve arkadaş şeklinde sıralanmaktadır. Algılanan Sosyal Destek Ölçeği’nin Cronbach Alpha katsayısı 0,708 olarak ölçülmüştür. Algılanan Sosyal Destek Ölçeği’nin özel bir insan boyutunun $\alpha$ katsayısı 0,545 , aile boyutunun $\alpha$ katsayısı 0,541 ve arkadaş boyutunun $\alpha$ katsayısı 0,556 olarak ölçülmüştür.

\subsection{Verilerin Analizi}

Araştırmada elde edilen veriler SPSS programı kullanılarak analiz edilmiştir. Verilerin analizinde; Cronbach Alpha, normallik testi, yüzde, ortalama, standart sapma, t testi, ANOVA testi, korelasyon ve regresyon analizi yapılmıştır. Araştırmanın istatistiksel analiz aşamasında öncelikle verilerin normal dağılıp dağılmadığına bakılmıştır. Kolmogorov-Smirnov testinde ( $\mathrm{p}=0.200 ; \mathrm{p}>0.05)$; ortalama ve ortanca değerler birbirine yakın değerler olduğu için (ortalama $=2.8439$; ortanca $=2.8400$ ) ve Skewness ve Kurtosis değerleri 1,96 ile $+1,96$ arasında olduğundan verilerin normal dağılım gösterdiği kabul edilerek parametrik testler uygulanmıştır (Akdoğdu ve Uşun, 2017:8). Bağımsız iki grup için toplanan puanların birbirinden istatistiksel anlamda farklı olup olmadığını tespit etmek için Bağımsız örneklem $t$ testi, üç veya daha çok bağımsız grubun bağımlı bir değişken ile aralarında istatistiksel anlamda farklılığın olup olmadığını saptamak için ise ANOVA testi yapılmıştır. Korelasyon analizi sonucunda ilişki saptanan ölçek ve alt boyutları arasında regresyon analizi yapılmışıır. 


\section{BULGULAR}

Tablo 1'de katılımcıların tanımlayıcı özelliklerine ilişkin bulgular sunulmuştur.

Tablo 1. Katılımcılar ile İlgili Tanımlayıcı Bulgular

\begin{tabular}{|c|c|c|}
\hline Cinsiyet & $\mathbf{n}$ & Yüzde (\%) \\
\hline Kadın & 187 & 54,2 \\
\hline Erkek & 158 & 45,8 \\
\hline \multicolumn{3}{|l|}{ Yaş } \\
\hline $18-25$ & 58 & 16,8 \\
\hline $26-35$ & 132 & 38,3 \\
\hline $36-45$ & 108 & 31,3 \\
\hline 46 ve üzeri & 47 & 13,6 \\
\hline \multicolumn{3}{|c|}{ Medeni Durum } \\
\hline Evli & 273 & 79.1 \\
\hline Bekar & 72 & 20.9 \\
\hline \multicolumn{3}{|c|}{ Eğitim Durumu } \\
\hline Lise & 57 & 16.5 \\
\hline Ön Lisans & 100 & 29.0 \\
\hline Lisans & 155 & 44.9 \\
\hline Lisansüstü & 33 & 9.6 \\
\hline \multicolumn{3}{|c|}{ Çalışan Statüsü } \\
\hline Hemşire & 105 & 30.4 \\
\hline Doktor & 97 & 28.1 \\
\hline Hasta Bakıcı & 46 & 13.3 \\
\hline T1bbi Sekreter & 62 & 18.1 \\
\hline Diğer & 35 & 10.1 \\
\hline \multicolumn{3}{|c|}{ Mesleki Deneyim } \\
\hline $1-5$ y1l & 44 & 12.8 \\
\hline $6-10 \mathrm{y} 11$ & 84 & 24.3 \\
\hline $11-15 \mathrm{y} 1 \mathrm{l}$ & 120 & 34.8 \\
\hline $16-20$ y1l & 50 & 14.5 \\
\hline 21 yıl ve üzeri & 47 & 13.6 \\
\hline \multicolumn{3}{|c|}{ Çalıştığı Kurumdaki Kıdem } \\
\hline $1-5$ y1l & 58 & 16.8 \\
\hline $6-10 \mathrm{y}_{11}$ & 97 & 28.1 \\
\hline $11-15$ yil & 110 & 31.9 \\
\hline $16-20$ yil & 47 & 13.6 \\
\hline 21 y1l ve üzeri & 33 & 9.6 \\
\hline \multicolumn{3}{|l|}{ Çalışılan Birim } \\
\hline Dahili Birim & 111 & 32.2 \\
\hline Cerrahi Birim & 77 & 22.3 \\
\hline Acil & 35 & 10.1 \\
\hline Yoğun Bakım & 41 & 11.9 \\
\hline Poliklinik & 45 & 13.1 \\
\hline Diğer & 36 & 10.4 \\
\hline TOPLAM & 345 & 100.0 \\
\hline
\end{tabular}

Tablo 1.'de görüldüğü üzere araştırmaya katılan çalışanların çoğunluğunu \%54,2 oranla kadınlar oluşturmaktadır. Çalışanlardan araştırmaya en çok katılım sağlayan yaş grubunun \%38,3 oranı ile 26-35 yaş 
grubu olduğu görülmektedir. Araştırmaya katılanların çoğunluğu \%79,1'i oranı ile evli katılımcıdan oluşmaktadır. Katılımcıların eğitim durumuna ilişkin veriler incelendiğinde, en yüksek katılım \%44,9 oranında lisans düzeyindedir. Katılımcıların meslek gruplarına bakıldığında en yüksek katılımı sağlayan mesleğin \%30,4 oranı ile hemşirelerden oluştuğu görülmektedir. Çalışanlardan araştırmaya en çok katılım sağlayan mesleki deneyim grubu \%34,8 oranı ile 11-15 yıl olduğu görülmektedir. Çalışanlardan araştırmaya en çok katılım sağlayan kurumdaki kıdemi en fazla olan grup \%31,9 oranı ile 11-15 y1l olduğu görülmektedir. Katılımcıların hastanede görev yaptıkları bölüme göre dağılımı incelendiğinde; en yüksek katılım \%32,2 oranında dahili birimlerden ve daha sonrasında da \%22,3 oranında cerrahi birimlerden olmuştur.

Sağlık çalışanlarının psikolojik yıldırma ve algılanan sosyal destek ölçek puanları incelendiğinde;

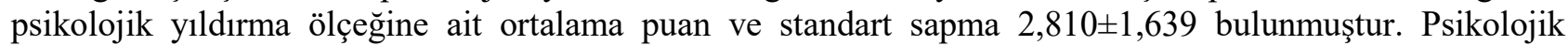
yıldırma ölçeği alt boyutları ortalama ve standart sapmaları incelendiğinde; iş arkadaşları ile ilişkiler alt boyutu $1,902 \pm 0,156$ puan, tehdit ve taciz alt boyutu $1,327 \pm 0,181$ puan, iş ve kariyer ile ilgili engellemeler alt boyutu $2,125 \pm 0,271$ puan, özel yaşama müdahale alt boyutu $2,110 \pm 0,354$ puan ve işe bağl1lık alt boyutu $3,481 \pm 0,842$ puan almıştır. Algılanan sosyal destek ölçeğine ait ortalama puan ve standart sapma 5,684 $\pm 0,245$ olarak bulunmuştur. Algılanan sosyal destek ölçeği alt boyutları ortalama ve standart sapmaları incelendiğinde; özel

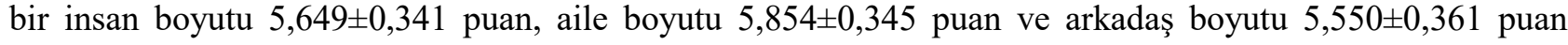
almıştır.

Tablo 2 ve 3'te katılımcıların tanımlayıcı özellikleri ile ölçek ve alt boyutları arasında fark olup olmadığına bakılmıştır.

Tablo 2. Sağlık Çalışanlarının Cinsiyet ve Medeni Durum Değişkenine Göre Psikolojik Yıldırma, Algılanan Sosyal Destek ve Alt Boyut Ortalamalarının Karşılaştırılması

\begin{tabular}{|c|c|c|c|c|c|c|c|}
\hline & \multirow{3}{*}{$\begin{array}{l}\text { Psikolojik } \\
\text { Yıldırma } \\
\text { Ölçeği } \\
2,932 \pm 1,798\end{array}$} & \multicolumn{5}{|c|}{ Alt Boyutlar } \\
\hline & & & \multirow{2}{*}{$\begin{array}{l}\text { İş } \\
\text { Arkadaşları } \\
\text { ile İlişkiler }\end{array}$} & $\begin{array}{l}\text { Tehdit ve } \\
\text { Taciz }\end{array}$ & \multirow{2}{*}{$\begin{array}{l}\begin{array}{l}\text { İss ve Kariyer } \\
\text { ile İlgili } \\
\text { Engellemeler }\end{array} \\
2,075 \pm 0,290\end{array}$} & \multirow{2}{*}{$\begin{array}{l}\begin{array}{l}\text { Özel } \\
\text { Yaşama } \\
\text { Müdahale }\end{array} \\
2,008 \pm 0,337\end{array}$} & \multirow{2}{*}{$\begin{array}{l}\text { İşe Bağlılık } \\
3,422 \pm 0,796\end{array}$} \\
\hline \multirow[t]{2}{*}{ Cinsiyet } & Kadın & & & $1,329 \pm 0,192$ & & & \\
\hline & Erkek & $2,665 \pm 1,421$ & $1,961 \pm 0,137$ & $1,323 \pm 0,169$ & $2,183 \pm 0,236$ & $2,210 \pm 0,344$ & $3,550 \pm 0,893$ \\
\hline \multirow{2}{*}{\multicolumn{2}{|c|}{ Test ve $p$ değeri }} & $\mathrm{t}=1,512$ & $\mathrm{t}=0,154$ & $\mathrm{t}=0,283$ & $\mathrm{t}=-3,722$ & $t=-5,508$ & $\mathrm{t}=-1,410$ \\
\hline & & $\mathrm{p}=0,124$ & $\mathrm{p}=\mathbf{0 , 0 0 0}$ & $\mathrm{p}=0,777$ & $\mathrm{p}=\mathbf{0 , 0 0 0}$ & $\mathrm{p}=\mathbf{0 , 0 0 0}$ & $\mathrm{p}=0,159$ \\
\hline \multirow{2}{*}{$\begin{array}{l}\text { Medeni } \\
\text { Durum }\end{array}$} & Evli & $2,947 \pm 1,743$ & $1,901 \pm 0,158$ & $1,313 \pm 0,176$ & $2,120 \pm 0,266$ & $2,096 \pm 0,366$ & $3,470 \pm 0,836$ \\
\hline & Bekar & $2,290 \pm 1,012$ & $1,904 \pm 0,151$ & $1,377 \pm 0,197$ & $2,142 \pm 0,292$ & $2,118 \pm 0,308$ & $3,527 \pm 0,872$ \\
\hline \multirow{4}{*}{\multicolumn{2}{|c|}{ Test ve $p$ değeri }} & $t=3,065$ & $\mathrm{t}=-0,149$ & $t=-2,662$ & $\mathrm{t}=-0,622$ & $t=-0,466$ & $\mathrm{t}=-0,527$ \\
\hline & & $\mathrm{p}=0,000$ & $\mathrm{p}=0,881$ & $p=0,014$ & $\mathrm{p}=0,534$ & $\mathrm{p}=0,641$ & $\mathrm{p}=0,598$ \\
\hline & & \multirow{2}{*}{$\begin{array}{l}\text { Algılanan } \\
\text { Sosyal } \\
\text { Destek }\end{array}$} & \multicolumn{5}{|c|}{ Alt Boyutlar } \\
\hline & & & \multicolumn{2}{|c|}{ Özel Bir İnsan } & Aile & \multicolumn{2}{|l|}{ Arkadaş } \\
\hline \multirow[t]{2}{*}{ Cinsiyet } & Kadın & $5,660 \pm 0,246$ & \multicolumn{2}{|l|}{$5,652 \pm 0,327$} & $5,842 \pm 0,347$ & \multicolumn{2}{|l|}{$5,486 \pm 0,361$} \\
\hline & Erkek & $5,712 \pm 0,242$ & \multicolumn{2}{|l|}{$5,645 \pm 0,360$} & $5,867 \pm 0,344$ & \multicolumn{2}{|l|}{$5,625 \pm 0,348$} \\
\hline \multirow{2}{*}{\multicolumn{2}{|c|}{ Test ve $p$ değeri }} & $t=-1,604$ & \multicolumn{2}{|l|}{$t=0,183$} & $t=-0,666$ & \multicolumn{2}{|l|}{$t=--3,604$} \\
\hline & & $p=0,049$ & \multicolumn{2}{|l|}{$p=0,853$} & $p=0,506$ & \multicolumn{2}{|l|}{$\mathrm{p}=\mathbf{0 , 0 0 0}$} \\
\hline \multirow{2}{*}{$\begin{array}{l}\text { Medeni } \\
\text { Durum }\end{array}$} & Evli & $5,688 \pm 0,246$ & \multicolumn{2}{|l|}{$5,663 \pm 0,342$} & $5,837 \pm 0,339$ & $5,562 \pm 0,366$ & \\
\hline & Bekar & $5,671 \pm 0,244$ & $5,597 \pm 0,337$ & & $5,913 \pm 0,361$ & $5,503 \pm 0,342$ & \\
\hline & & $t=0,508$ & $t=1,468$ & & $t=-1,592$ & $t=1,278$ & \\
\hline Test ve po & ğeri & $\mathrm{p}=\mathbf{0 , 6 1 3}$ & $\mathrm{p}=\mathbf{0}, \mathbf{1 4 7}$ & & $\mathbf{p}=\mathbf{0 , 1 0 0}$ & $\mathbf{p}=\mathbf{0 , 2 2 0}$ & \\
\hline
\end{tabular}

Sağlık çalışanlarının cinsiyete göre psikolojik yıldırma düzeyleri ile alt boyutları karşılaştırıldığında; iş arkadaşları ile ilişkiler, iş ve kariyer ile ilgili engellemeler ve özel yaşama müdahale alt boyutunda anlamlı düzeyde farklılık bulunmuştur $(\mathrm{p}<0,05)$. Fakat sağlık çalışanlarında cinsiyete göre tehdit ve taciz, işe bağl1lık ve toplam psikolojik yıldırma puanları arasında ise farklılık çıkmamıştır ( $\mathrm{p}>0,05)$. Sağlık çalışanlarının medeni 
duruma göre psikolojik yıldırma düzeyleri ile alt boyutları karşılaştırıldığında; toplam psikolojik yıldırma ile tehdit ve taciz alt boyutunda anlamlı düzeyde farklılık bulunmuştur $(\mathrm{p}<0,05)$. İş arkadaşları ile ilişkiler, iş ve kariyer ile ilgili engellemeler, özel yaşama müdahale, işe bağlılık puanları arasında ise farklılık çıkmamıştır $(\mathrm{p}>0,05)$. Sağlık çalışanlarının cinsiyete göre toplam algılanan sosyal destek ile alt boyutları karşılaştırıldığında; özel bir insan ve aile boyutunda, istatistiksel açıdan anlamlı düzeyde bir fark olmadığ $(\mathrm{p}>0,05)$ fakat cinsiyete göre arkadaş ve toplam algılanan sosyal destek arasında fark olduğu saptanmıştır $(\mathrm{p}<0,05)$.

Sağlık çalışanlarının medeni duruma göre toplam algılanan sosyal destek ile alt boyutları karşılaştırıldığında; medeni durum değişkeni ile toplam algılanan sosyal destek algıları ve alt boyutları arasında istatistiksel açıdan anlamlı düzeyde bir fark olmadığı saptanmıştır $(\mathrm{p}>0,05)$.

Tablo 3. Sağlık Çalışanlarının Yaş, Eğitim durumu, Birim ve Mesleki Deneyim Değişkenine Göre Psikolojik Yıldırma ve Alt Boyut Ortalamalarının Karşılaştırılması

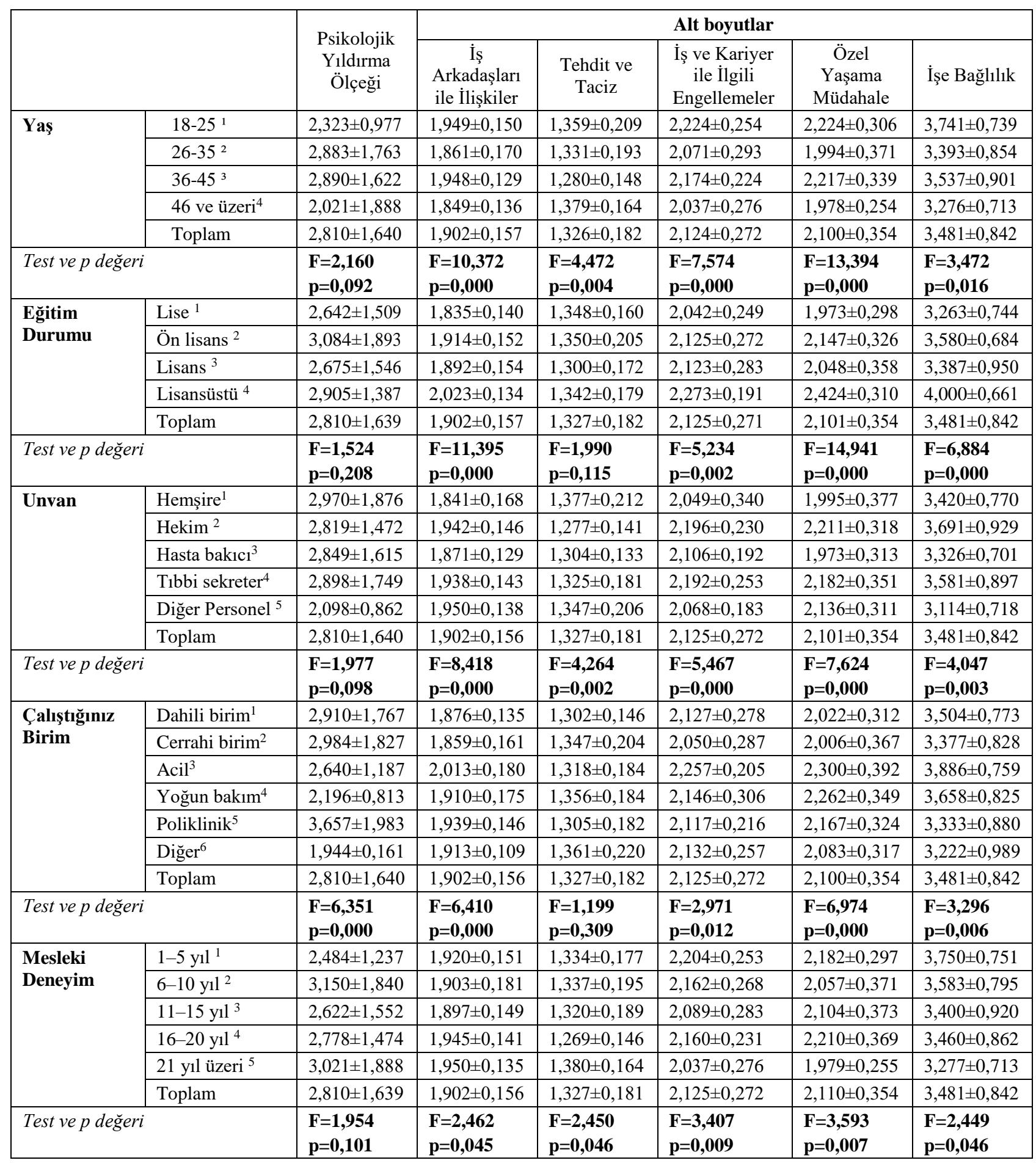


Sağlık çalışanlarının eğitim durumuna göre toplam psikolojik yıldırma düzeyleri ile alt boyutları karşılaştırıldığında; iş arkadaşları ile ilişkiler, iş ve kariyer ile ilgili engellemeler, özel yaşama müdahale, işe bağlılık puanları arasında anlamlı düzeyde farklılık bulunmuştur $(\mathrm{p}<0,05)$. Toplam psikolojik yıldırma ile tehdit ve taciz alt boyutunda anlamlı düzeyde farklılık çıkmamıştır $(\mathrm{p}>0,05)$. Farkın hangi gruplardan kaynaklandığını tespit etmek için ise Tukey testi kullanılmıştır. Yapılan analiz sonucunda; İş arkadaşları ile ilişkiler, iş ve kariyer ile ilgili engellemeler, özel yaşama müdahale ve işe bağlılık boyutlarında farklılığın lisansüstü grubundan kaynaklandığ $1(4>2>3>1)$ görülmektedir.

Sağlık çalışanlarının unvana göre toplam psikolojik yıldırma düzeyleri ile alt boyutları karşılaştırıldığında; tüm alt boyutlarda anlamlı düzeyde farklılık bulunmuştur $(\mathrm{p}<0,05)$. Toplam psikolojik yıldırma puanı arasında ise bir farklılık yoktur $(\mathrm{p}>0,05)$. Farkın hangi gruplardan kaynaklandığını tespit etmek için ise Tukey testi kullanılmıştır. Yapılan analiz sonucunda; iş arkadaşları ile ilişkiler boyutunda farklılı̆̆ın diğer personel grubundan $(5>2>4>1)$; tehdit ve taciz boyutunda farklılığın hemşire grubundan (1>2), iş ve kariyer ile ilgili engellemeler boyutunda farklılığın hekim grubundan $(2>4>1>5)$, özel yaşama müdahale boyutunda farklılığın hekim grubundan $(2>4>1>3)$, işe bağglılı boyutunda farklılığın hekim grubundan $(2>4>5)$ kaynaklandığ görülmektedir.

Sağlık çalışanlarının çalıştığınız birim değişkenine göre toplam psikolojik yıldırma düzeyleri ile alt boyutları karşılaştırıldığında; iş arkadaşları ile ilişkiler, iş ve kariyer ile ilgili engellemeler, özel yaşama müdahale, işe bağlılık ve toplam psikolojik yıldırma puanları arasında anlamlı düzeyde farklılık bulunmuştur $(p<0,05)$. Fakat çalışılan birim ile tehdit ve taciz alt boyutu arasında bir farklılık yoktur $(p>0,05)$. Gruplar arası homojenite olmadığından Post Hoc Tests ile hangi gruplar arasında anlamlı fark olup olmadığını anlamak için Games-Howell testi ile analiz yapılmıştır. Yapılan analiz sonucunda; iş arkadaşları ile ilişkiler, iş ve kariyer ile ilgili engellemeler boyutunda farklılığın acil biriminden $(3>1>2)$, özel yaşama müdahale boyutunda farklılığın acil biriminden $(3>4>1>2)$, işe bağlılık boyutunda farklılığın acil biriminden $(3>4>5>6)$ kaynaklandığg görülmektedir.

Sağlık çalışanlarının mesleki deneyim değişkenine göre toplam psikolojik yıldırma düzeyleri ile alt boyutları karş1laştırıldığında; tüm alt boyutlarda anlamlı düzeyde farklılık bulunmuştur $(\mathrm{p}<0,05)$. Fakat mesleki deneyim ile toplam psikolojik yıldırma arasında bir farkl11ı yoktur $(\mathrm{p}>0,05)$. Farkın hangi gruplardan kaynaklandığını tespit etmek için ise Tukey testi kullanılmıştır. Yapılan analiz sonucunda; iş arkadaşları ile ilişkiler ve tehdit ve taciz boyutunda farklılığın 21 yıl ve üzeri grubundan $(5>1)$, iş ve kariyer ile ilgili engellemeler, özel yaşama müdahale ve işe bağl1lı boyutunda farklılığın 1-5 y1l grubundan $(1>5)$ kaynaklandığı görülmektedir.

Sağlık çalışanlarının kurumdaki mesleki deneyim değişkenine göre toplam psikolojik yıldırma düzeyleri ile alt boyutları karşılaştırıldığında; tehdit ve taciz ve iş ve ile ilgili engellemeler boyutunda anlamlı düzeyde farklılık bulunmuştur $(\mathrm{p}<0,05)$. Fakat kurumdaki mesleki deneyim ile iş arkadaşları ile ilişkiler, özel yaşama müdahale, işe bağlılık ve toplam psikolojik yıldırma arasında farklılık çıkmamıştır ( $p>0,05)$. Farkın hangi gruplardan kaynaklandığını tespit etmek için ise gruplar arası homojenite olmadığından Post Hoc Tests ile Games Howell testi kullanılmıştır. Yapılan analiz sonucunda; tehdit ve taciz boyutunda farklılığın 21 yıl ve üzeri $(5>4>2)$, iş ve kariyer ile ilgili engellemeler boyutunda farklılığın 1-5 yıl $(1>2>5)$ grubundan kaynaklanmaktadır.

Tablo 4. Sağlık Çalışanlarının Yaş, Eğitim durumu, Birim ve Mesleki Deneyim Değişkenine Göre Algılanan Sosyal Destek ve Alt Boyut Ortalamalarının Karşılaştırılması

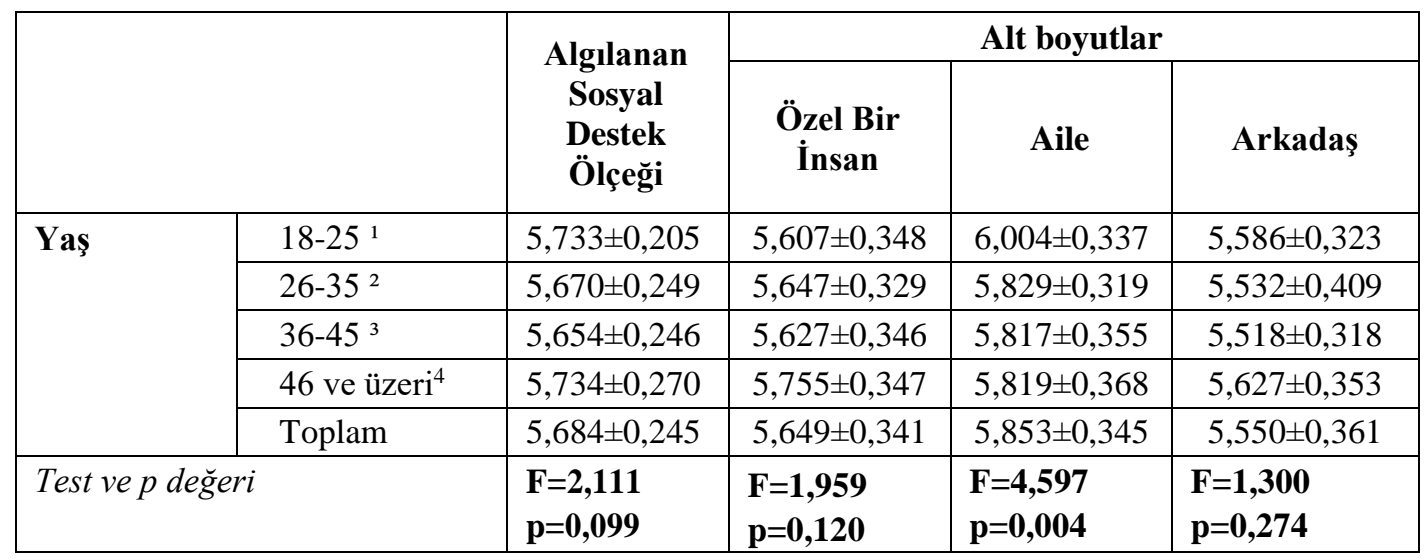




\begin{tabular}{|c|c|c|c|c|c|}
\hline \multirow{5}{*}{$\begin{array}{l}\text { Eŭitim } \\
\text { Durumu }\end{array}$} & Lise $^{1}$ & $5,687 \pm 0,269$ & $5,671 \pm 0,384$ & $5,815 \pm 0,377$ & $5,574 \pm 0,337$ \\
\hline & Ön lisans ${ }^{2}$ & $5,672 \pm 0,249$ & $5,592 \pm 0,344$ & $5,902 \pm 0,331$ & $5,520 \pm 0,385$ \\
\hline & Lisans $^{3}$ & $5,688 \pm 0,242$ & $5,664 \pm 0,331$ & $5,840 \pm 0,339$ & $5,558 \pm 0,360$ \\
\hline & Lisansüstü $^{4}$ & $5,702 \pm 0,209$ & $5,712 \pm 0,294$ & $5,833 \pm 0,357$ & $5,560 \pm 0,343$ \\
\hline & Toplam & $5,684 \pm 0,245$ & $5,649 \pm 0,342$ & $5,853 \pm 0,345$ & $5,550 \pm 0,361$ \\
\hline \multicolumn{2}{|c|}{ Test ve p değeri } & $\begin{array}{l}F=0,157 \\
p=0,925\end{array}$ & $\begin{array}{l}F=1,478 \\
p=0,220\end{array}$ & $\begin{array}{l}F=1,012 \\
p=0,388\end{array}$ & $\begin{array}{l}F=0,350 \\
p=0,789\end{array}$ \\
\hline \multirow[t]{6}{*}{ Unvan } & Hemşire $^{1}$ & $5,630 \pm 0,234$ & $5,650 \pm 0,283$ & $5,793 \pm 0,347$ & $5,448 \pm 0,379$ \\
\hline & Hekim $^{2}$ & $5,716 \pm 0,242$ & $5,709 \pm 0,344$ & $5,827 \pm 0,372$ & $5,611 \pm 0,344$ \\
\hline & Hasta bakıc1 ${ }^{3}$ & $5,688 \pm 0,274$ & $5,685 \pm 0,396$ & $5,831 \pm 0,361$ & $5,549 \pm 0,344$ \\
\hline & Tibbi sekreter ${ }^{4}$ & $5,653 \pm 0,225$ & $5,557 \pm 0,339$ & $5,887 \pm 0,278$ & $5,516 \pm 0,319$ \\
\hline & Diğer Personel $^{5}$ & $5,810 \pm 0,235$ & $5,600 \pm 0,412$ & $6,079 \pm 0,256$ & $5,750 \pm 0,348$ \\
\hline & Toplam & $5,684 \pm 0,245$ & $5,649 \pm 0,341$ & $5,854 \pm 0,345$ & $5,550 \pm 0,361$ \\
\hline \multicolumn{2}{|c|}{ Test ve $p$ değeri } & $\begin{array}{l}F=4,373 \\
p=0,002\end{array}$ & $\begin{array}{l}F=2,215 \\
p=0,067\end{array}$ & $\begin{array}{l}F=5,095 \\
p=0,001\end{array}$ & $\begin{array}{l}F=5,928 \\
p=0,000\end{array}$ \\
\hline \multirow{7}{*}{$\begin{array}{l}\text { Çalıştığınız } \\
\text { Birim }\end{array}$} & Dahili birim $^{1}$ & $5,655 \pm 0,248$ & $5,630 \pm 0,347$ & $5,887 \pm 0,364$ & $5,448 \pm 0,376$ \\
\hline & Cerrahi birim $^{2}$ & $5,674 \pm 0,252$ & $5,656 \pm 0,374$ & $5,792 \pm 0,335$ & $5,575 \pm 0,361$ \\
\hline & $\operatorname{Acil}^{3}$ & $5,645 \pm 0,257$ & $5,600 \pm 0,286$ & $5,807 \pm 0,316$ & $5,529 \pm 0,358$ \\
\hline & Yoğun bakım ${ }^{4}$ & $5,665 \pm 0,216$ & $5,592 \pm 0,295$ & $5,768 \pm 0,380$ & $5,634 \pm 0,317$ \\
\hline & Poliklinik $^{5}$ & $5,728 \pm 0,178$ & $5,700 \pm 0,299$ & $5,878 \pm 0,291$ & $5,606 \pm 0,347$ \\
\hline & Diğer $^{6}$ & $5,801 \pm 0,286$ & $5,743 \pm 0,394$ & $5,993 \pm 0,313$ & $5,667 \pm 0,327$ \\
\hline & Toplam & $5,684 \pm 0,245$ & $5,649 \pm 0,341$ & $5,854 \pm 0,345$ & $5,550 \pm 0,361$ \\
\hline \multicolumn{2}{|c|}{ Test ve p değeri } & $\begin{array}{l}F=2,530 \\
p=0,029\end{array}$ & $\begin{array}{l}F=1,195 \\
p=0,311\end{array}$ & $\begin{array}{l}F=2,607 \\
p=0,025\end{array}$ & $\begin{array}{l}F=3,377 \\
p=0,005\end{array}$ \\
\hline \multirow{6}{*}{$\begin{array}{l}\text { Mesleki } \\
\text { Deneyim }\end{array}$} & $1-5 \mathrm{y} y l^{1}$ & $5,739 \pm 0,224$ & $5,591 \pm 0,382$ & $6,000 \pm 0,354$ & $5,625 \pm 0,339$ \\
\hline & $6-10 \mathrm{yil}^{2}$ & $5,672 \pm 0,235$ & $5,702 \pm 0,319$ & $5,830 \pm 0,325$ & $5,482 \pm 0,391$ \\
\hline & $11-15{\mathrm{y} 11^{3}}^{3}$ & $5,684 \pm 0,249$ & $5,615 \pm 0,341$ & $5,867 \pm 0,329$ & $5,571 \pm 0,355$ \\
\hline & $16-20{\mathrm{y} 1 l^{4}}^{4}$ & $5,612 \pm 0,234$ & $5,595 \pm 0,315$ & $5,765 \pm 0,359$ & $5,475 \pm 0,328$ \\
\hline & 21 yil üzeri $^{5}$ & $5,734 \pm 0,269$ & $5,755 \pm 0,348$ & $5,819 \pm 0,368$ & $5,628 \pm 0,353$ \\
\hline & Toplam & $5,684 \pm 0,245$ & $5,649 \pm 0,342$ & $5,854 \pm 0,345$ & $5,550 \pm 0,361$ \\
\hline \multicolumn{2}{|c|}{ Test ve p değeri } & $\begin{array}{l}F=2,206 \\
p=0,068\end{array}$ & $\begin{array}{l}F=2,632 \\
p=0,034\end{array}$ & $\begin{array}{l}F=3,134 \\
p=0,015\end{array}$ & $\begin{array}{l}F=2,434 \\
p=0,047\end{array}$ \\
\hline
\end{tabular}

Sağlık çalışanlarının yaşa göre toplam algılanan sosyal destek ile alt boyutları karşılaştırıldığında; çalışanların yaş ile toplam algılanan sosyal destek algıları arasında istatistiksel açıdan anlamlı düzeyde bir fark olmadığı $(\mathrm{p}>0.05)$ fakat çalışanların yaş ile aile boyutu arasında istatistiksel açıdan anlamlı düzeyde bir fark olduğu bulunmuştur $(\mathrm{p}<0.05)$. Farkın hangi gruplardan kaynaklandığını tespit etmek için ise Tukey testi kullanılmıştır. Yapılan analiz sonucunda; Aile boyutunda farklılığın 18-25 yaş $(1>2>4>3)$ grubundan kaynaklandığı görülmektedir.

Sağlık çalışanlarının eğitim durumuna göre toplam algılanan sosyal destek ile alt boyutları karşılaş̧ırıldığında; çalışanların eğitim durumu ile toplam algılanan sosyal destek puanı ve alt boyutları arasında istatistiksel açıdan anlamlı düzeyde bir fark olmadığı saptanmıştır ( $\mathrm{p}>0.05)$.

Sağlık çalışanlarının unvana göre toplam algılanan sosyal destek ile alt boyutları karşılaştırıldığında; çalışanların unvana göre ile toplam algılanan sosyal destek algıları, aile ve arkadaş alt boyutu arasında istatistiksel açıdan anlamlı düzeyde bir fark olduğu saptanmıştır $(\mathrm{p}<0.05)$. Fakat unvan ile özel bir insan alt boyutu arasında farklılık yoktur ( $>0,05)$. Gruplar arası homojenite olduğundan Post Hoc Tests ile hangi guruplar arasında anlamlı fark olup olmadığını anlamak için Tukey testi ile analiz yapılmıştır. Yapılan analiz sonucunda; aile ve arkadaş boyutunda farklılığın diğer personel grubundan $(5>2>1)$ kaynaklandığı görülmektedir.

Sağlık çalışanlarının çalıştığınız birime göre algılanan sosyal destek ile alt boyutları karşılaştırıldığında; çalıştı̆̆ınız birim ile toplam algılanan sosyal destek ve aile ile arkadaş boyutunda, istatistiksel açıdan anlamlı düzeyde bir fark olduğu bulunmuştur $(\mathrm{p}<0,05)$. Fakat çalıştığınız birim ile özel bir insan alt boyutu arasında farkl1lık yoktur $(\mathrm{p}>0,05)$. Gruplar arası homojenite olduğundan Post Hoc Tests ile hangi guruplar arasında anlamlı fark olup olmadığını anlamak için Tukey testi ile analiz yapılmıştır. Yapılan analiz sonucunda; aile 
boyutunda farklılı̆̆ın diğer grubundan $(6>2>4)$ arkadaş boyutunda da farklılığın diğer birim grubundan $(6>1)$ kaynaklandığı görülmektedir.

Sağlık çalışanlarının mesleki deneyime göre algılanan sosyal destek ile alt boyutlanı karşılaştırıldığında; özel, aile ve arkadaş alt boyutu ile çalışanların mesleki deneyim ile toplam algılanan sosyal destek algıları arasında istatistiksel açıdan anlamlı düzeyde bir fark olduğu saptanmıştır $(\mathrm{p}<0,05)$. Fakat mesleki deneyim ile toplam algılanan sosyal destek arasında farklılık yoktur $(\mathrm{p}>0,05)$. Gruplar arası homojenite olduğundan Post Hoc Tests ile hangi guruplar arasında anlamlı fark olup olmadığını anlamak için Tukey testi ile analiz yapılmıştır. Yapılan analiz sonucunda; aile boyutunda farkın 1-5 yıl grubundan (1>4) kaynaklandığ görülmektedir. Özel ve arkadaş boyutunda farkın 21 yıl ve üzeri grubundan $(5>1)$ kaynaklandığ 1 görülmektedir.

Sağlık çalışanlarının algılanan sosyal destek puan ortalamaları ile çalıştığınız kurumdaki deneyiminiz değişkenine göre yapılan analiz sonucunda, çalışanların çalıştı̆̆ınız kurumdaki kıdemleri ile toplam algılanan sosyal destek ve alt boyutları arasında istatistiksel açıdan anlamlı bir fark olmadığı saptanmıştır ( $>0,05)$.

Sağlık çalışanlarının psikolojik yıldırma ve alt boyutları ile algılanan sosyal destek alt boyutları arasındaki ilişkiyi saptamak için korelasyon analizi yapılmıştır (Tablo 5).

Tablo 5'e göre çalışanların psikolojik yıldırma düzeyleri ile algılanan sosyal destek düzeyleri arasında negatif yönlü düşük düzeyde ilişki bulunmuştur $(\mathrm{r}=-0,154 ; \mathrm{p}<0,01)$. Çalışanların psikolojik yıldırma düzeyleri ile aileye yönelik sosyal destek algıları arasında düşük düzeyde, negatif yönde anlamlı bir ilişki bulunmuştur $(\mathrm{r}=-0,213 ; \mathrm{p}<0,01)$. Çalışanların psikolojik yıldırma düzeyleri ile arkadaş grubu algıları arasında düşük düzeyde, negatif yönde anlamlı bir ilişki bulunmuştur $(r=-0,156 ; p<0,01)$. Çalışanların psikolojik yıldırma alt boyutu olan iş arkadaşları ile ilişkiler grubu ile algılanan sosyal destek alt boyutu olan özel bir insan grubuna yönelik algıları arasında düşük düzeyde, negatif yönde anlamlı bir ilişki bulunmuştur $(r=-0,115 ; \mathrm{p}<0,05)$. Korelasyon matrisine bakıldığında çalışanların iş arkadaşları ile ilişkiler düzeyleri ile aileye yönelik algıları arasında düşük düzeyde, pozitif yönde anlamlı bir ilişki bulunduğu görülmektedir $(r=0,149 ; p<0,01)$. İlgili matris takip edildiğinde çalışanların iş ve kariyer ile ilgili engellemeler düzeyleri ile aileye yönelik sosyal destek algıları arasında düşük düzeyde, pozitif yönde anlamlı bir ilişki bulunmuştur $(r=0,142 ; p<0,01)$ (Kalayc1, 2010).

Tablo 5. Ölçekler ve Alt Boyutları Arası Korelasyon Analizi

\begin{tabular}{|c|c|c|c|c|c|c|c|c|c|c|c|}
\hline \multicolumn{2}{|l|}{ DEĞİŞKENLER } & 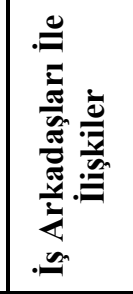 & 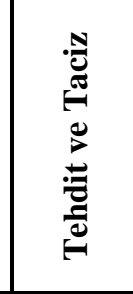 & 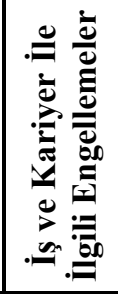 & 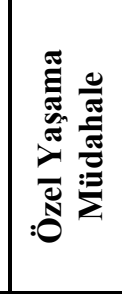 & 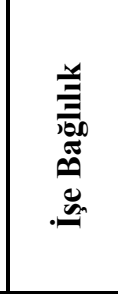 & 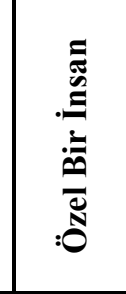 & $\stackrel{\frac{2}{2}}{\frac{\pi}{2}}$ & $\begin{array}{l}\frac{\pi}{\pi} \\
\frac{\pi}{\pi} \\
\frac{\pi}{i} \\
\end{array}$ & 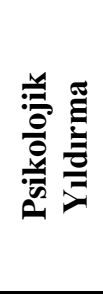 & 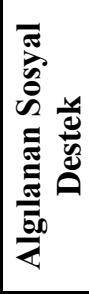 \\
\hline \multirow{2}{*}{$\begin{array}{l}\text { İş Arkadaşları ile } \\
\text { İlişkiler }\end{array}$} & $\mathrm{r}$ & 1 & & & & & & & & & \\
\hline & $\mathrm{p}$ & & & & & & & & & & \\
\hline \multirow[t]{2}{*}{ Tehdit ve Taciz } & $\mathrm{r}$ & $0,159 * *$ & 1 & & & & & & & & \\
\hline & $\mathrm{p}$ & 0,003 & & & & & & & & & \\
\hline \multirow{2}{*}{$\begin{array}{l}\text { İş ve Kariyer ile } \\
\text { İlgili Engellemeler } \\
\end{array}$} & $\mathrm{r}$ & $0,289 * *$ & $-0,046$ & 1 & & & & & & & \\
\hline & $\mathrm{p}$ & 0,000 & 0,394 & & & & & & & & \\
\hline \multirow{2}{*}{$\begin{array}{l}\text { Özel Yaşama } \\
\text { Müdahale } \\
\end{array}$} & $\mathrm{r}$ & $0,743^{* *}$ & $0,249^{* *}$ & $0,190^{* *}$ & 1 & & & & & & \\
\hline & $\mathrm{p}$ & 0,000 & 0,000 & 0,000 & & & & & & & \\
\hline \multirow[t]{2}{*}{ İşe Bağl1lık } & $\mathrm{r}$ & $0,115^{*}$ & $-0,113^{*}$ & $0,709^{* *}$ & $0,124^{*}$ & 1 & & & & & \\
\hline & $\mathrm{p}$ & 0,032 & 0,036 & 0,000 & 0,021 & & & & & & \\
\hline \multirow[t]{2}{*}{ Özel bir insan } & $\mathrm{r}$ & $-0,115^{*}$ & $-0,010$ & 0,040 & $-0,045$ & 0,010 & 1 & & & & \\
\hline & $\mathrm{p}$ & 0,033 & 0,850 & 0,462 & 0,405 & 0,856 & & & & & \\
\hline \multirow[t]{2}{*}{ Aile } & $\mathrm{r}$ & $0,149 * *$ & 0,031 & $0,142^{* * *}$ & 0,079 & $0,138^{*}$ & $0,167^{\text {*** }}$ & 1 & & & \\
\hline & $\mathrm{p}$ & 0,006 & 0,561 & 0,008 & 0,142 & 0,010 & 0,002 & & & & \\
\hline \multirow[t]{2}{*}{ Arkadaş } & $\mathrm{r}$ & 0,032 & $-0,042$ & 0,009 & 0,074 & 0,047 & $0,273^{\text {** }}$ & $0,271^{* *}$ & 1 & & \\
\hline & $\mathrm{P}$ & 0,556 & 0,433 & 0,875 & 0,170 & 0,387 & 0,000 & 0,000 & & & \\
\hline
\end{tabular}




\begin{tabular}{|c|c|c|c|c|c|c|c|c|c|c|c|}
\hline \multirow{2}{*}{$\begin{array}{l}\text { Psikolojik Yıldırma } \\
\text { Düzeyleri }\end{array}$} & $\mathrm{r}$ & $-0,054$ & 0,014 & 0,099 & $-0,048$ & $0,108 *$ & 0,049 & $-0,213^{* *}$ & $-0,156^{* *}$ & 1 & \\
\hline & $\mathrm{p}$ & 0,313 & 0,792 & 0,065 & 0,373 & 0,045 & 0,363 & 0,000 & 0,004 & & \\
\hline \multirow{2}{*}{$\begin{array}{l}\text { Alg1lanan Sosyal } \\
\text { Destek Düzeyleri }\end{array}$} & $\mathrm{r}$ & 0,032 & $-0,011$ & 0,089 & 0,053 & 0,092 & $0,677^{* *}$ & $0,680^{* *}$ & $0,746^{* *}$ &,$- 154 * *$ & 1 \\
\hline & $\mathrm{p}$ & 0,555 & 0,841 & 0,098 & 0,329 & 0,086 & 0,000 & 0,000 & 0,000 & 0,004 & \\
\hline \multicolumn{2}{|l|}{ TOPLAM } & 345 & 345 & 345 & 345 & 345 & 345 & 345 & 345 & 345 & 345 \\
\hline \multicolumn{12}{|c|}{$* * 0,01$ düzeyinde anlamlı bir ilişki vardır. } \\
\hline \multicolumn{12}{|c|}{ * 0,05 düzeyinde anlamlı bir ilişki vardır. } \\
\hline
\end{tabular}

Korelasyon analizi sonucu ilişki çıkan değişkenler arasında regresyon analizi yapılmıştır. Sağlık çalışanların algılanan sosyal desteğe yönelik algıları psikolojik yıldırmaya yönelik algıyı etkilemektedir" ilişkisi için bağımsız değişken olarak ele alınan algılanan sosyal destek ile bağımlı değişken olarak ele alınan psikolojik yıldırma regresyon analizine tabi tutulmuş ve bulgular Tablo 6'da verilmiştir.

Tablo 6. Psikolojik Yıldırma ve Algılanan Sosyal Destek Arasında Regresyon Analizi

\begin{tabular}{|c|c|c|c|c|c|c|}
\hline Bağımsız değişken & $\mathbf{B}$ & Std. Hata & $\mathbf{t}$ & $\mathbf{F}$ & $\mathbf{p}$ & $\mathbf{R}^{2}$ \\
\hline Sabit & 8,644 & 2,029 & 4,260 & \multirow[t]{2}{*}{8,284} & \multirow[t]{2}{*}{0,004} & \multirow[t]{2}{*}{0,024} \\
\hline Alg1lanan Sosyal Destek & $-1,026$ & 0,357 & $-2,878$ & & & \\
\hline Sabit & 8,719 & 1,469 & 5,934 & \multirow[t]{2}{*}{16,230} & \multirow[t]{2}{*}{0,000} & \multirow[t]{2}{*}{0,045} \\
\hline Aile alt boyutu & $-1,009$ & 0,251 & $-4,029$ & & & \\
\hline Sabit & 6,736 & 1,345 & 5,008 & \multirow[t]{2}{*}{8,557} & \multirow[t]{2}{*}{0,004} & \multirow[t]{2}{*}{0,024} \\
\hline Arkadaş alt boyutu & $-0,707$ & 0,242 & $-2,925$ & & & \\
\hline \multicolumn{7}{|c|}{ Bağımlı değişken: Psikolojik Yıldırma } \\
\hline
\end{tabular}

Analiz sonuçlarına göre, psikolojik yıldırma ve algılanan sosyal destek puanı istatistiksel olarak anlamlı sonuç vermektedir $(\mathrm{F}=8,284 ; \mathrm{p}=0,004)$. Bu sonuç araştırmada algılanan sosyal destek ile psikolojik yıldırma algisını tahmin etmenin istatistiksel olarak mümkün olduğu anlamına gelmektedir. Algılanan sosyal desteğin psikolojik yıldırma üzerindeki etkisi $\% 2,4$ oranında açıklanmaktadır $\left(\mathrm{R}^{2}=0,024\right)$. Psikolojik yıldırma ve aile puanına baktığımızda istatistiksel olarak anlamlı sonuç vermektedir $(F=16,230 ; p=0,000)$. Bu sonuç ailenin, psikolojik yıldırma etkisini \%4,5 oranında açıklamaktadır $\left(\mathrm{R}^{2}=0,045\right)$. Psikolojik yıldırma ve arkadaş puanı arasında da anlamlı sonuç görülmektedir $(\mathrm{F}=8,557 ; \mathrm{p}=0,004)$. Bu sonuç arkadaşın, psikolojik yıldırma etkisini $\% 2,4$ oranında açıklamaktadır $\left(\mathrm{R}^{2}=0,024\right)$.

Analiz sonuçlarına göre, iş arkadaşları ile ilişkiler ve özel bir insan puanı istatistiksel olarak anlamlı bir sonuç vermektedir $(\mathrm{F}=4,602 ; \mathrm{p}=0,033)$. Bu sonuç araştırmada özel bir insan ile iş arkadaşları ile ilişkiler algısını tahmin etmenin istatistiksel olarak mümkün olduğu anlamına gelmektedir. Özel bir insan boyutunun, arkadaş ile ilişkiler üzerindeki etkisi \% 1,3 oranında açılanmaktadır $\left(\mathrm{R}^{2}=0,013\right)$. İş arkadaşları ile ilişkiler ve aile puanı istatistiksel olarak anlamlı sonuç vermektedir $(\mathrm{F}=7,742 ; \mathrm{p}=0,006)$. Bu sonuç araştırmada aile ile iş arkadaşları ile ilişkiler algısını tahmin etmenin istatistiksel olarak mümkün olduğu anlamına gelmektedir. Ailenin, arkadaş ile ilişkiler etkisini \%2,2 oranında açıklamaktadır $\left(\mathrm{R}^{2}=0,022\right)$. İş ve kariyer ile ilgili engellemeler ve aile puanı istatistiksel olarak anlamlı sonuç vermektedir $(\mathrm{F}=7,051 ; \mathrm{p}=0,008)$. Bu sonuç araştırmada aile ile iş ve kariyer ile ilgili engellemeler algısını tahmin etmenin istatistiksel olarak mümkün olduğu anlamına gelmektedir. Ailenin, iş ve kariyer ile ilgili engellemeler etkisini $\% 2,0$ oranında açıklamaktadır $\left(\mathrm{R}^{2}=0,020\right)$. İşe bağl1lı ve aile puanı istatistiksel olarak anlamlı sonuç vermektedir $(\mathrm{F}=6,654$; $\mathrm{p}=0,010)$. Bu sonuç araştırmada aile ile işe bağl1lık algısını tahmin etmenin istatistiksel olarak mümkün olduğu anlamına gelmektedir. Ailenin, işe bağlılık etkisini \%1,9 oranında açıklamaktadır $\left(\mathrm{R}^{2}=0,019\right)$.

\section{TARTIŞMA}

Çalışmada sağlık çalışanlarının psikolojik yıldırma ve algılanan sosyal destek düzeyleri incelenmiştir.

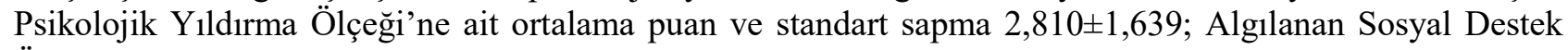

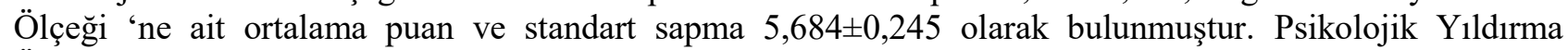
Ölçeği'nin en yüksek ortalamaya sahip işe bağlllık alt boyutuna ait ortalama puan ve standart sapma 3,481 $\pm 0,842$; Algılanan Sosyal Destek Ölçeği'nin en yüksek ortalamaya sahip aile boyutuna ait ortalama puan ve standart sapma 5,854 $\pm 0,345$ olarak bulunmuştur. Cinsiyet, yaş, eğitim durumu, unvan değişkenlerine göre psikolojik yıldırma puanları arasında anlamlı düzeyde farklılık bulunmuştur $(\mathrm{p}<0,05)$. Cinsiyet, yaş, unvan ve mesleki deneyim değişkenine göre algılanan sosyal destek puanı arasında anlamlı düzeyde farklılık çıkmıştır $(\mathrm{p}<0,05)$. 
Araştırma bulgularına göre; sağlık çalışanlarının cinsiyete göre işyerinde psikolojik yıldırmaya uğrama düzeyi bakımından aralarında anlamlı düzeyde bir farklılık bulunmuştur $(p<0,05)$. Sadece psikolojik yıldırmanın tehdit ve taciz ile işe bağl1lık alt boyutlarında anlamlı düzeyde bir farklılık bulunmamıştır $(p>0,05)$. Erkek çalışanların psikolojik yıldırma puan ortalamasının kadın çalışanlardan daha yüksek olduğu saptanmıştır. Bunun nedeni erkek çalışanların çalışma hayatlarında kendilerini daha zorunlu hissetmeleri ve işini kaybetme korkusundan kaynaklandığı söylenebilmektedir. Benzer olarak Yıldız ve diğ. (2013: 23)'nin yaptığı araştırmada erkek çalışanların kadın çalışanlardan daha fazla psikolojik yıldırmaya maruz kaldıkları saptanmıştır. Cemaloğlu ve Ertürk (2007: 357) tarafindan yapılan çalışmada da aynı sonuca ulaşılmıştır. Farklı olarak Çarıkçı ve Yavuz (2009: 11)'un yaptığı çalışma sonucunda çalışanların cinsiyetlerine göre psikolojik yıldırma algıları değişmemektedir.

Sağlık çalışanlarının işyerinde psikolojik yıldırma alt boyutlarının yaş değişkenine göre anlamlı düzeyde farklılık gösterdiği sonucuna ulaşılmıştır $(\mathrm{p}<0,05)$. 18-25 yaş ve 46 ve üzeri yaş gruplarındaki sağllk çalışanlarının işyerinde psikolojik yıldırmanın bütün alt boyut puan ortalamasının diğer yaş gruplarından anlamlı düzeyde daha yüksek düzeyde olduğu bulunmuştur. Çalışanların yaşları ile ters bir orantı göstermektedir. Yani gençlerin diğer yaş gruplarına oranla psikolojik yıldırmaya daha maruz kaldıkları düşünülmektedir. 18-25 yaş grubunda yıldırmanın fazla olması bu yaş grubunun işe yeni başlamış olmalarına ve henüz mesleki anlamda yeterli olmamalarına bağlıdır. Çarıkçı ve Yavuz (2009: 11)'un yaptığı çalışma sonucunda da çalışanların yaşları büyüdükçe psikolojik yıldırma algılarıyla ilgili tutum puanları azalmaktadır.

Sağlık çalışanlarının işyerinde psikolojik yıldırma alt boyutlarının medeni durum değişkenine göre anlamlı düzeyde farklılık göstermediği sonucuna ulaşı1mıştır $(\mathrm{p}<0,05)$. Sadece psikolojik yıldırmanın tehdit ve taciz alt boyutunda medeni durum değişkenine göre anlamlı düzeyde bir farklılık bulunmuştur. Medeni durum bakımından bekar çalışanların psikolojik yıldırmanın alt boyutu olan tehdit ve taciz puan ortalamasının evli çalışanlardan daha yüksek olduğu saptanmıştır. Bekar çalışanların evlilere göre kendilerini daha yalnız hissetmeleri ve sosyal destek (eş ve çocuk) eksikliği nedeniyle tehdit ve tacizi daha yoğun yaşadıkları düşünülmektedir. Palaz ve diğ. (2008: 12)'nın yaptığı çalışmada psikolojik yıldırmaya maruz kalma oranı evlilerde \%77,4 ve bekar, dul ve ayrı yaşayanlarda ise \%22,6 oranında bulunmuştur. Kılıç ve diğ. (2016: 6)'nın yaptığı çalışmada çalışanların medeni durumlarına bakıldığında psikolojik yıldırmaya maruz kalma davranışlarının medeni duruma göre farklılaşmadığı saptanmıştır. Aksoy (2008: 79)'un yaptığı çalışmada ise bekar çalışanların daha fazla psikolojik yıldırmaya maruz kaldığı saptanmıştır.

Sağlık çalışanlarının işyerinde psikolojik yıldırma ve alt boyutlarının eğitim durumu değişkenine göre anlamlı düzeyde farklılık gösterdiği sonucuna ulaşılmıştır $(p<0,05)$. Sadece psikolojik yıldırmanın tehdit ve taciz alt boyutunda eğitim durumu değişkenine göre anlamlı düzeyde bir farklılık bulunmamıştır. Eğitim durumu bakımından lisansüstü çalışanların psikolojik yıldırmanın alt boyutlarının puan ortalamasının lise, ön lisans ve lisans düzeyindeki çalışanlardan anlamlı düzeyde daha yüksek olduğu saptanmıştır. Buna neden olarak lisansüstü çalışanların daha bilinçli olması, yıldırmayı daha çabuk fark edebilmesi ve olayları daha fazla irdelemesi gösterilebilir. Yıldız ve diğ. (2013: 25)'nin yaptığı araştırmada da lisansüstü eğitime sahip sağlık çalışanları daha fazla psikolojik yıldırmaya maruz kalmaktadır. Palaz ve diğ. (2008: 12)'nin yaptığı çalışmada lise ve altı eğitime sahip çalışanlara $\% 19,8$ oranında ve üniversite ve lisans üstü çalışanlara ise $\% 80,2$ oranında psikolojik taciz uygulandığı saptanmıştır. Sezerel (2007: 115)'in yaptı̆̆ 1 araştırmada ise, ön lisans mezunlarının daha fazla psikolojik yıldırmaya maruz kaldıkları belirtilmiştir.

Sağlık çalışanlarının unvan değişkenine göre işyerinde psikolojik yıldırma ve alt boyutları arasında bir farklılık vardır $(\mathrm{p}<0,05)$. Psikolojik yıldırmanın tehdit ve taciz alt boyutunda hemşire grubunun puan ortalaması diğer gruplardan (hekim, hasta bakıcı, tıbbi sekreter ve diğer personel) daha fazladır. Hemşirelerin yoğun iş temposu altında çalışıyor olması ve kendi işleri dışında da iş yükleniyor olması hemşirelerde yıldırmanın yoğun yaşanmasına sebep olmaktadır. Psikolojik yıldırmanın iş ve kariyer ile ilgili engellemeler, özel yaşama müdahale ve işe bağlılık alt boyutlarının hekim grubunun puan ortalamaları diğer gruplardan daha fazla çıkmıştır. Hekimler arasında ast üst meselesinin fazla olması üstten kaynaklı yıldırmaya maruz kalmaları ve gereksiz işler yapmak zorunda kalmaları da yıldırmanın yaşanmasına sebep olmaktadır. Yiğitbaş ve Deveci (2011: 5)'nin yaptığı çalışmada psikolojik yıldırmaya maruz kalanların daha çok hemşireler, sonrasında ise hekimler ve sağlık memurları oldukları görülmüştür.

Sağlık çalışanlarının birim değişkenine göre işyerinde psikolojik yıldırma ve alt boyutlarının çalıştığınız anlamlı düzeyde farklılık gösterdiği sonucuna ulaşılmıştır $(p<0,05)$. Sadece psikolojik yıldırmanın tehdit ve taciz alt boyutunda bir farklılık bulunmamıştır. Psikolojik yıldırmanın bütün alt boyutlarında acil grubunun puan ortalamasının diğer gruplardan (dahili, cerrahi, yoğun bakım, poliklinik ve diğer birim) daha yüksek olduğu görülmektedir. Acilde görev alan sağlık çalışanları daha yoğun ve daha karmaşık bir ortamda çalıştıkları için yıldırmayı daha yoğun yaşayabilmektedirler. 
Sağlık çalışanlarının işyerinde mesleki deneyim değişkenine göre psikolojik yıldırma alt boyutları arasında bir farklılık göstermektedir $(\mathrm{p}<0,05)$. Fakat mesleki deneyim ile toplam psikolojik yıldırma arasında bir farklılık yoktur ( $p>0,05)$. Yıldız ve diğ. (2013: 27)'nin yaptığı araştırmada kıdem değişkenine göre istatistiksel açıdan anlamlı fark bulunamamıştır.

Sağlık çalışanlarının cinsiyet değişkenine göre algılanan sosyal destek ve arkadaş alt boyutunda anlamlı düzeyde farklılık gösterdiği sonucuna ulaşılmıştır $(\mathrm{p}<0,05)$. Cinsiyet bakımından erkek çalışanların algılanan sosyal destek puan ortalamasının kadın çalışanlardan daha yüksek olduğu saptanmıştır. Gümüş (2015: 68)' ün yaptığı çalışma sonucunda da erkek çalışanların algıladığı sosyal destek düzeyleri kadınların algıladıkları sosyal destek düzeyinden daha fazladır. Bu durum erkeklerin eş desteğinin kadınlardan daha fazla olduğu yönünde yorumlanabilmektedir.

Sağlık çalışanlarının algılanan sosyal destek alt boyutu olan arkadaş boyutunda yaş değişkenine göre anlamlı düzeyde farklılık gösterdiği sonucuna ulaşılmıştır $(\mathrm{p}<0,05) .18-25$ yaş arasındaki grupta arkadaş alt boyut puan ortalamasının diğer yaş gruplarına göre daha yüksek olduğu bulunmuştur. Bu yaş grubu sorunlarını daha çok arkadaşları ile paylaşmasında kaynaklanabilmektedir. Yaş ilerledikçe arkadaşın yerini aile ve eş almaktadır. Farklı olarak Uyan (2014: 75) yaptığı çalışma sonucunda yaş grupları arasında algılanan sosyal destek düzeyinde herhangi bir farklılık bulamamıştır.

Sağlık çalışanlarının medeni durum, eğitim durumu ve çalıştığınız kurumdaki kıdem değişkenine göre algılanan sosyal destek ve alt boyutları arasında bir farklılık göstermediği sonucuna ulaşılmıştır ( $>>0,05)$. Benzer olarak Sönmezsoy (2018: 50)'un yaptığı çalışmada bireylerin medeni durumlarına göre algıladıkları sosyal destek düzeyleri arasında bir farklılık olmadığı belirlenmiştir. Farklı olarak Kaya ve diğ. (2012: 365)'nin yaptığı çalışma sonucunda evli çiftlerin diğerlerine oranla aileden sağladığı sosyal destek daha fazladır. Turgut (2014: 159)'ün çalışmasında eğitim düzeyi arttıkça algılanan sosyal destek düzeyi puanının da arttı̆̆ gözlemlenmiştir. Argon ve Selvi (2013: 198), tarafindan yapılan araştırmada bu araştırmanın bulgularına benzer olarak sosyal desteğin kıdeme göre değişmediğini tespit etmiştir.

Sağlık çalışanlarında unvan değişkenine göre algılanan sosyal destek ve alt boyutları arasında bir farklılık gösterdiği sonucuna ulaşılmıştır $(\mathrm{p}<0,05)$. Toplam algılanan sosyal destek, aile ve arkadaş alt boyutlarının diğer sağlık çalışanları grubu puan ortalamasının diğer gruplara göre (hemşire, hekim, hasta bakıcı ve tıbbi sekreter) daha yüksek olduğu bulunmuştur. Çivilidağ (2011: 157) yaptığı çalışmada unvan değişkenine göre algılanan sosyal destek arasında anlamlı düzeyde farklılık göstermediğini saptamıştır.

Sağlık çalışanlarının birim değişkenine göre özel bir insan alt boyutu ile arasında anlamlı düzeyde bir farklılık göstermediği sonucuna ulaşılmıştır $(p>0,05)$. Birim değişkenine göre toplam algılanan sosyal destek, aile ve arkadaş alt boyutları arasında anlamlı düzeyde bir farklılık bulunmuştur $(p<0,05)$. Algılanan sosyal desteğin aile ve arkadaş alt boyutlarında diğer personel grubu puan ortalamasının diğer gruplara (dahili birim, cerrahi birim, acil, yoğun bakım ve poliklinik birim) göre daha yüksektir.

Sağlık çalışanlarının mesleki deneyim değişkenine göre algılanan sosyal destek ve alt boyutlarının anlamlı düzeyde farklılık gösterdiği sonucuna ulaşılmıştır $(p<0,05)$. Algılanan sosyal desteğin özel bir insan ve arkadaş alt boyutunun 21 yıl ve üzeri grubu puan ortalamasının diğer yaş gruplarından daha yüksek olduğu bulunmuştur. Aile alt boyutunun ise 1-5 yıl grubu puan ortalamasının diğer gruplara göre daha fazla olduğu görülmektedir.

Sağlık çalışanlarının psikolojik yıldırma düzeyleri ile algılanan sosyal destek düzeyleri arasında negatif yönlü ve düşük düzeyde ilişki bulunmuştur ( $\mathrm{r}=-0,154$; $\mathrm{p}<0,01)$. Benzer şekilde Çivilidağ (2011: 181)'in yaptı̆̆ çalışmada da psikolojik yıldırma düzeyleri ile algılanan sosyal destek düzeyleri arasında negatif yönlü ilişki bulunmuştur $(\mathrm{r}=-0,157 \mathrm{p}<0,05)$. Algılanan sosyal destek düzeyi arttıkça psikolojik yıldırma düzeyinde azalma görülmektedir. Çalışmada, algılanan sosyal destek algısının \%2,4'ünün psikolojik yıldırma tarafından; algılanan sosyal destek düzeyinin, özel bir insan alt boyut algısının \%1,3'ünün arkadaş ile ilişkiler alt boyutu tarafından açıklandığı görülmektedir. Algılanan sosyal destek düzeyinin, arkadaş alt boyut algısının \%2,4'ünün ise psikolojik yıldırma tarafından açıklandığı tespit edilmiştir. Özellikle algılanan sosyal desteğin alt boyutu olan aile desteğinin; iş arkadaşları ile ilişkiler, iş ve kariyer ile ilgili engellemeler, işe bağlılık ve psikolojik yıldırma üzerinde ters yönlü ilişkisi vardır $(\mathrm{p}<0,05)$. Yani, sağlık çalışanlarının aile desteği arttıkça psikolojik yıldırmaya maruz kalma puanlarının da azalacağı düşünülmektedir. Ayrıca algılanan sosyal desteğin psikolojik yıldırmaya temel etki etmesi ve tampon görevi görmesi sağlı çalışanlarının psikolojik yıldırma düzeyleri üzerine pozitif yönde etki etmektedir. 


\section{SONUÇ VE ÖNERILLR}

Araştırmamızda psikolojik yıldırma ve algılanan sosyal destek ilgili elde ettiğimiz sonuçlar literatürle uyumlu ve yapılan araştırmaların sonuçlarıyla da tutarlılık göstermektedir. Psikolojik yıldırmayla mücadele yollarından biri olan algılanan sosyal desteğin çalışanlar için önemi ve gerekliliği ortaya konulmuştur. Çalışanlarda algılanan sosyal destek ne kadar fazla olursa bireyin psikolojik yıldırma karşısında o kadar güçlü olacağ 1 düşünülmektedir. Özellikle aile desteği yıldırma konusunda daha etkili olmakla beraber arkadaş ve özel birinin desteğine de ihtiyaç olduğu görülmektedir.

Araştırma sonuçları doğrultusunda sağlık kurumlarında psikolojik yıldırmanın azaltılması ve sosyal desteğin artırılmasına yönelik;

- Çalışmamızda hemşire ve hekimlerde psikolojik yıldırma düzeyi daha fazla bulunmuş olması sebebiyle; sağlık kurumlarında çalışanların görev tanımlarının, iş yüklerinin ve iş tasarımlarının gözden geçirilmesi, eleman sayılarının arttırılması önerilmektedir.

- 18-25 yaş grubunda psikolojik yıldırma düzeyi fazla çıkmıştır. Bu yaş grubunun işe yeni başlayan grup olması nedeniyle işe uyum ve hizmet içi programlara psikolojik yıldırma ile ilgili eğitimlerin dahil edilmesi önerilmektedir.

- Aile desteğinin, diğer destek gruplarına göre psikolojik yıldırmaya etkisi daha fazla çıkmış olmasından dolayı, özel insan ve arkadaş desteğinin de arttırılmasına yönelik çalışmalar yapılması önerilmektedir.

- Sağlık kurumlarında çalışma arkadaşlarından gelen yardımseverlik davranışlarının örgüt kültürü olarak yerleştirilmesine yönelik çalışmalar yapılması önerilmektedir. 


\section{KAYNAKÇA}

Abualrub, Raeda Fawzi, (2004) "Job Stress, Job Performance, And Social Support Among Hospital Nurses", Journal of Nursing Scholarship 36, s. 73-78.

Aiello, Antonio, Deitinger, Patrizia, Nardella, Christian ve Michela Bonafede, (2008) "A Tool for Assessing the Risk of Mobbing in Organizational Environments: The "Val.Mob." Scale, Prevention Today 3, s. 9- 24.

Akdoğdu, Eda ve Salih Uşun, (2017) "Sınıf Öğretmenliği Lisans Programının Öğretmen Adaylarının Görüşleri Doğrultusunda Bağlam, Girdi, Süreç ve Ürün (CIPP) Modeli İle Değerlendirilmesi” İlköğretim Online 16, s. 826847.

Akeren, İhsan, (2017) “Üniversite Öğrencilerinde Algılanan Sosyal Destek ve Güvenilirlik ile Psikolojik Yardım İhtiyacının İncelenmesi”, Yüksek Lisans Tezi, Atatürk Üniversitesi Eğitim Bilimleri Enstitüsü, Erzurum.

Akın, Mahmut, (2008) “Örgütsel destek, sosyal destek ve iş/aile çatışmalarının yaşam tatmini üzerindeki etkileri” Sosyal Bilimler Enstitüsü Dergisi 25, s. 141-170.

Aksoy, Fikret, (2008) “Psikolojik Şiddetin (Mobbing) Sağlık Çalışanlarına Etkisi”, Doktora Tezi, Marmara Üniversitesi Sağlık Bilimleri Enstitüsü, Sağlık Kurumları Yöneticiliği Anabilim Dalı, İstanbul.

Ardahan, Melek, (2006) “Sosyal Destek ve Hemşirelik”, Atatürk Üniversitesi Hemşirelik Yüksekokulu Dergisi 9, s. 1-8. Argon, Türkan ve Çiğdem Selvi, (2013) “İlköğretim Okulu Öğretmenlerinin Sahip Oldukları Girişimcilik Değerleri ve Algıladıkları Sosyal Destek Düzeyleri Arasındaki İlişkisi”, International Journal of Social Science 6, s. 179-206.

Bruhn, John, G. ve Billy Philips, (1984) "Measuring social support: A synthesis of current approaches", Journal of Behavioral Medicine, 7, s. 151-169.

Cassel, J. (1976) "The Contribution of Social Enviroment to Host Resistance", The Johns Hopkins University School of Hygiene and Public Health 104, s. 107-123.

Cemaloğlu, Necati ve Abbas Ertürk, (2007) “Öğretmenlerin Maruz Kaldıkları Yıldırma Eylemlerinin Cinsiyet Yönünden İncelenmesi”, Türk Eğitim Bilimleri Dergisi 5, s. 345-362.

Chappell, Duncan ve Vittorio Di Martino, (1998) "Violence At Work", Geneva, International Labor Organization, s. 2.

Çarıkçı, İlker, Hüseyin ve Hüseyin Yavuz, (2009) "Çalışanlarda Mobbing (Psikolojik Şiddet) Algısı: Sağlık Sektörü Çalışanları Üzerine Bir Araştırma”, Süleyman Demirel Üniversitesi Sosyal Bilimler Enstitüsü Dergisi 10, s. 11.

Çeçen, Rezan, Ayşe, (2008) “Öğrencilerinin Cinsiyetlerine ve Ana Baba Tutum Algılarına Göre Yalnızlık ve Sosyal Destek Düzeylerinin İncelenmesi”, Türk Eğitim Bilimleri Dergisi 6, s. 416.

Çetinkaya, Neslihan, (2016) "Belediye Çalışanlarının Psikolojik Yıldırma ile Güdülenme Düzeyleri Arasındaki İlişki (Mersin İli Örneği)”, Yüksek Lisans Tezi, Toros Üniversitesi, Sosyal Bilimler Enstitüsü, İşletme Anabilim Dalı, Mersin.

Çimen, Mesut ve Serkan Deniz, (2017) Sağlık Kurumları Yönetiminde Örgütsel Davranış Konuları, 1. bs., Nobel Akademik Yayıncılık, Ankara.

Çivilidağ, Aydın, (2011) "Üniversitelerdeki Öğretim Elemanlarının Psikolojik Taciz (Mobbing), İş Doyumu ve Algılanan Sosyal Destek Düzeyleri”, Doktora Tezi, Selçuk Üniversitesi, Eğitim Bilimleri Enstitüsü, Eğitim Bilimleri Anabilim Dalı, Psikolojik Danışmanlık ve Rehberlik Bilim Dalı, Konya.

Department of Health, (1999) "Campaignto Stop Violence against Staff Working in the NHS: NHS Zero Tolerance one", Department of Health, London, s. 226

Eker, Doğan, Arkar, Haluk ve Hülya Yaldız, (2001) “Çok Boyutlu Algılanan Sosyal Destek Ölçeğinin Gözden Geçirilmiş Formunun Faktör Yapısı, Geçerlik ve Güvenirliği’”, Türk Psikiyatri Dergisi 12, s. 17-25

Elmac1, Figen, (2006) "Parçalanmış ve Bütünlüğünü Koruyan Aileye Sahip Ergenlerin Depresyon ve Uyum Düzeylerinde Sosyal Desteğin Rolü”, Kuram ve Uygulamada Eğitim Bilimleri Dergisi 6, s. 405-423.

Göymen, Yusuf, (2020) "İş Hayatında Mobbing ve Mobbingle Başa Çıkma Yolları”, Toros Üniversitesi, İISBB Sosyal Bilimler Dergisi 7, s. 31-60.

Gümüş, Hülya, (2015) "Evli Bireylerin Algılanan Sosyal Destek Düzeyi ve Yaşam Doyumları İle Problem Çözme Becerileri Arasındaki İlişki”, Yüksek Lisans Tezi, Yalova Üniversitesi, Sosyal Bilimler Enstitüsü, Sosyal Hizmet Anabilim Dalı, Sosyal Hizmet Bilim Dalı, Yalova.

Heather K, Spence Laschinger, Ashley L, Grau, Joan Finegan ve Piotr Wilk, (2010) "New Graduate Nurses” Experiences of Bullying and Burn Out In Hospital Settings, Journal of Advanced 12, s.2732-2742.

Hirigoyen, M.F., (2000) Manevi Taciz: Gündelik Hayatta Sapkın Şiddet. (Çev: Heval.Bucak), 1.bs., Güncel Yayıncılık, İstanbul.

Hogh, Annie ve Andrea Dofradottir, (2001) "Coping with Bullying in the Workplace”, European Journal of Work and Organizational Psychology 10, s. 485-495.

Hubert, Adrienne ve March Van Veldhoven, (2001) "Risk Sectors For Undesirable Behavior and Mobbing”, European Journal of Work and Organizational Psychology 10, s. 415-424.

İlhan, Ümit, (2010) “İşyerinde Psikolojik Tacizin (Mobbing) Tarihsel Arka Planı ve Türk Hukuk Sisteminde Yeri”, Ege Akademik Bakış 10, s. 1-12.

Kalaycı, Şeref, (2010) SPSS Uygulamalı Çok Değişkenli İstatistik Teknikleri, Asil Yayın Dağıtım, Ankara.

Karabacak, Büşra ve Serkan Hacıcaferoğlu, (2020) “Antrenörlerin Çalışma Ortamlarında Maruz Kaldıkları Yıldırma (Mobbing) Davranışlarının İncelenmesi”, Journal of Social and Humanities Sciences Research 7, s. 2443-2450. 
Karc1oğlu, Fatih ve Sevil Akbaş, (2010) “İşyerinde Psikolojik Şiddet ve İş Tatmini İlişkisi”, Atatürk Üniversitesi İktisadi ve İdari Bilimler Dergisi 24, s. 139-162.

Kaya, Didem, Akgemci, Tahir ve Adnan Çelik, (2012) "A Research Levels of Perceived Social Support on The Responsible Persons of The Hospital Units”, Ç.Ü. Sosyal Bilimler Enstitüsü Dergisi 21, s. 357-370.

Kılıç, Nurhayat ve Havva Tel, (2017) "Sağlık Çalışanlarında Mobbing Algısı ve İş Doyumunun Belirlenmesi”, Florence Nightingale Hemşirelik Dergisi 25, s. 31-40.

Kılıç, Taşkın, Çiftçi, Fatma ve Şeyma Şener, (2016) "Sağlık Çalışanlarında Mobbing ve İlişkili Faktörler”, Journal of Health and Nursing Management 3, s. 6

Kırel, Çiğdem, (2008) Örgütlerde Psikolojik Taciz (Mobbing) ve Yönetimi, Anadolu Üniversitesi Yayınları, Eskişehir.

Kowalczuk, Krstyna, Jankowiak, Barbara, Krajewska-Kulak, Elzbieta, Sierakowska, Matylda, Lewko, Jolanta ve Krstyna Klimaszewska, (2007) "Exposure The Doctors to Aggression in The Workplace", Advances in Medical Sciences 32, s. 89-92

Kozaklı, Hatice, (2006) "Üniversite Öğrencilerinde Yalnızlık ve Sosyal Destek Düzeyleri Arasındaki İlişkinin Karşı1laştırılması", Yüksek Lisans Tezi, Mersin Üniversitesi, Sosyal Bilimler Enstitüsü, Mersin.

Kurt, Esra, (2013) "Algılanan Sosyal Destek ve İş Performansı İlişkisinde İşe Bağlılığın Aracı Etkisi: Turizm İşletmelerinde Bir Araştırma", Yüksek Lisans Tezi, Hacettepe Üniversitesi, Sosyal Bilimler Enstitüsü, İşletme Anabilim Dalı, Yönetim Organizasyon ve Örgütsel Davranış Bilim Dalı, Ankara.

Laleoğlu, Ayşegül ve Emine Özmete, (2013) "Mobbing Ölçeği: Geçerlik ve Güvenirlik Çalışması”, Sosyal Politikalar Çalışmaları, s. 19-20.

Leymann, Heinz, (1990) "Mobbing and Psychological Terror at Workplaces", Yiolence and Victims 5, s.119- 126

Mete, Ceren, (2017) “İzmir'de Yaşayan Roman Ergenlerin Psikolojik Sağlamlıklarının Algılanan Sosyal Destek, Mizah Kullanımı ve Sosyal Bağllık Düzeylerine Göre İncelenmesi”. Yüksek Lisans Tezi, Ege Üniversitesi, Sosyal Bilimler Enstitüsü, Rehberlik ve Psikolojik Danışmanlık Bilim Dalı, İzmir.

Miles, Matthew B. (1969) "Planned Change and Organizational Health: Figre and Ground". Organizations and Human Behavior: Focus on Schools. Fred Carver and Thomas J. Sergiovanni (Eds.) McGraw- Hill Book Company. New york.

Özdemir, Deniz, (2017) "Onkoloji Eğitim Hemşireliği Biriminde Eğitim Alan Meme Kanseri Hastalarında Stresle Başa Çıkma Yolları ve Algılanan Sosyal Destek Düzeyleri”, Yüksek Lisans Tezi, Selçuk Üniversitesi, Sağlık Bilimleri Enstitüsü, Hemşirelik Anabilim Dalı, Konya.

Özyolcu, Ertuğrul, (2015) "Eğitim Yönetimi Temelinde Öğretmenlerin ve Yöneticilerin Aşırı İş Yükü, Tükenmişlik ve Sosyal Destek Durumlarının İncelenmesi”, Yüksek Lisans Tezi, Yakın Doğu Üniversitesi, Eğitim Bilimleri Enstitüsü, Eğitim Yönetimi Denetimi Ekonomisi ve Planlaması Anabilim Dalı, Lefkoşa.

Pai Hsiang-Chu ve Sheuan Lee, (2011) "Risk Factors For Workplace Violence in Clinical Registered Nurses in Taiwan", Journal Clinical Nursing, (9-10), s.1405-1412.

Palaz Serap, Özkan, Sultan, Sarı, Necla, Göze, Fehim, Şahin, Nurdan ve Ömrüye Akkurt, (2008) "İ̧̧ Yerinde Psikolojik Taciz (Mobbing) Davranışları Üzerine Bir Araştırma; Bandırma Örneği”, "İş, Güç" Endüstri İlişsileri ve İnsan Kaynakları Dergisi 10, s. 12.

Person, Judith, (1986) "The Definition and Measurement of Social Support", Journal of Counseling \& Development 64, s. 390-396.

Redman, Tom, (2006) "The Consequences of Perceived Age Discrimination Amongst Older Police Officers: Is Social Support a Buffer?", British Journal of Management 17, s. 167-175.

Resch, Martin and Marion Schubinski, (1996) "Mobbing- Prevention Management in Organizations", European Journal of Work and Organizational Psychology 5, s. 295-307.

Sandvik, Pamela, Lutgen, (2006) "Burned By Bullying in The American Workplace: Prevalence, Perception, Degree, And Impact", Journal of Management Studies, s. 5-6.

Sezerel, Hakan, (2007) “Örgütlerde Mobbing'in Etkileri ve Tülomsaş-Türkiye Lokomotif ve Motor Sanayi AŞ'de Bir Uygulama", Yüksek Lisans Tezi, Anadolu Üniversitesi, Sosyal Bilimler Enstitüsü, Eskişehir.

Sorensen, Silvia. ve Martin Pinquart, (2010) "Influences on Loneliness in Older Adults: A Meta Analysis", Basic and Applied Social Psychology 23, s. 245-266.

Sönmezsoy, Nureddin, (2018) “Akademisyenlerin Algıladıkları Sosyal Destek ve İş Doyumu Arasındaki İlişki”, Yüksek Lisans Tezi, Maltepe Üniversitesi, Psikoloji Anabilim Dalı, İstanbul.

Sönmeztekin, Burcu, (2016) "Sağlık Sektöründe Üst Yönetimin Mobbing Algısı Üzerine Nitel Bir Araştırma", Yüksek Lisans Tezi, Arel Üniversitesi, Sosyal Bilimler Enstitüsü, İşletme Anabilim Dalı, İşletme Yönetimi Programı, İstanbul.

TBMM, (2011) İşyerinde Psikolojik Taciz (Mobbing) ve Çözüm Önerileri Komisyon Raporu, Kadın Erkek Fırsat Eşitliği Komisyonu Yayınları, Nisan 2011, Ankara. https://www.tbmm.gov.tr/komisyon/kefe/docs/komisyon_rapor_no_6.pdf)

Tetik, Semra, (2010) "Mobbing Kavramı: Birey ve Örgütler Açısından Önemi”, Karamanoğlu Mehmetbey Üniversitesi Sosyal ve Ekonomik Araştırmalar Dergisi 12, s. 1-10.

Turgut, Gizem, (2014) “Algılanan Sosyal Destek ve Duygusal Zekâ Düzeyinin İş Tatminine Etkisinin Devlette Çalışan Üç Farklı Meslek Grubunda Karşılaştırılması: Mühendis, Doktor ve Öğretmen”, Yüksek Lisans Tezi, Maltepe Üniversitesi Sosyal Bilimler Enstitüsü, İstanbul. 
Uyan, Adil, (2014) “Ergenlerde Algılanan Stres ile Sosyal Destek Arasındaki İlişki”, Yüksek Lisans Tezi, İstanbul Arel Üniversitesi, Sosyal Bilimler Enstitüsü, Psikoloji Ana Bilim Dalı, Psikoloji Programı İstanbul.

Weber Andreas, Hörmann, Georg ve Volker Köllner, (2007) "Mobbing a work related risk factor of service based society?", Gesunheitswesen 69, s.267-276.

Yıldırım, Dilek, (2009) "Mobbing ve İş Yerinde Taciz”, Sağlıcakla Dergisi 12, s. 12-15.

Yıldırım, Aytolan ve Dilek Yıldırım, (2007) "Mobbing the Workplace By Peers and Managers: Mobbing Experienced By Nurses Working İn Healthcare Facilities İn Turkey and its Effect on Nurses", Journal of Clinical Nursing 16, s. $1444-1453$

Yıldırım Tuğçe, (2017) "Üniversite Öğrencilerinde Benlik Saygısı ile Algılanan Sosyal Destek ve Yaşam Doyumu Arasındaki İlişkinin İncelenmesi”, Yüksek Lisans Tezi, Haliç Üniversitesi, Sosyal Bilimler Enstitüsü, Psikoloji Ana Bilim Dalı, Klinik Psikoloji Programı, İstanbul.

Yıldız, Gültekin, Akbolat, Mahmut ve Oğuz Işık, (2013) "Psikolojik Taciz ve Örgütsel Bağlılık: Sağlık Çalışanları Üzerine Bir Araştırma”, Manas Sosyal Araştırmalar Dergisi 2, s. 27.

Yiğitbaş, Çağla ve Süleyman Erhan, Deveci, (2011) "Sağlık Çalışanlarına Yönelik Mobbing”, Mesleki Sağlık ve Güvenlik Dergisi 1, s. 5.

Yılmaz, Yöney, Esma ve Erhan Kılınç, (2020) “Bankacılık Sektöründe Psikolojik Yıldırmanın Çalışanların İş ve Yaşam Tatmini Üzerindeki Etkisinin İncelenmesi”, İktisadi İdari ve Siyasal Araştırmalar Dergisi 11, s. 34-52.

Zencirkıran Mehmet ve Aşkın Keser, (2018), Örgütsel Davranış, 1. bs., Dora Basın Dağıtım.

Zimet, Gregory, Nancy W. Dahlem, Sara G. Zimet ve Gordon K. Farley, (1988) "The Multidimensional Scale of Perceived Social Support", Journal of Personality Assessment 52, s. 30-4. 